\title{
Suppression of progesterone-enhanced hyperactivation in hamster spermatozoa by estrogen
}

\author{
Masakatsu Fujinoki \\ Department of Physiology, School of Medicine, Dokkyo Medical University, Mibu, Tochigi 321-0293, Japan \\ Correspondence should be addressed to M Fujinoki; Email: fujinoki@dokkyomed.ac.jp
}

\begin{abstract}
In this study, I examined whether sperm hyperactivation in hamster is regulated by steroid hormones such as estrogen (estradiol, $E_{2}$ ) and progesterone. Although sperm hyperactivation was enhanced by progesterone, $17 \beta$-estradiol $\left(17 \beta E_{2}\right)$ itself did not affect sperm hyperactivation. However, $17 \beta \mathrm{E}_{2}$ suppressed progesterone-enhanced hyperactivation in a concentration-dependent manner through non-genomic pathways when spermatozoa were exposed to $17 \beta \mathrm{E}_{2}$ at the same time or before exposure to progesterone. When spermatozoa were exposed to $17 \beta \mathrm{E}_{2}$ after exposure to progesterone, $17 \beta \mathrm{E}_{2}$ did not suppress progesterone-enhanced hyperactivation. Moreover, $17 \alpha$-estradiol, an inactive isomer of $E_{2}$, did not suppress progesterone-enhanced hyperactivation. Observations using a FITC-conjugated $17 \beta \mathrm{E}_{2}$ showed that it binds to the acrosome region of the sperm head. Binding of $17 \beta \mathrm{E}_{2}$ to spermatozoa was not inhibited by progesterone, although $17 \beta \mathrm{E}_{2}$ did not suppress progesterone-enhanced hyperactivation when spermatozoa were exposed to $17 \beta \mathrm{E}_{2}$ after exposure to progesterone. On the other hand, binding of progesterone to spermatozoa was also not inhibited by $17 \beta \mathrm{E}_{2}$ even if progesterone-enhanced hyperactivation was suppressed by $17 \beta \mathrm{E}_{2}$. Although tyrosine phosphorylations of sperm proteins were enhanced by progesterone, enhancement of tyrosine phosphorylations by progesterone was suppressed by $17 \beta \mathrm{E}_{2}$. Moreover, tyrosine phosphorylations were inhibited by $17 \beta \mathrm{E}_{2}$ when only $17 \beta \mathrm{E}_{2}$ was added to the medium. From these results, it is likely that $17 \beta \mathrm{E}_{2}$ competitively suppresses progesterone-enhanced hyperactivation through the inhibition of tyrosine phosphorylations via non-genomic pathways.

Reproduction (2010) 140 453-464
\end{abstract}

\section{Introduction}

After capacitation, mammalian spermatozoa fertilize eggs. Capacitated spermatozoa exhibit the acrosome reaction (AR) and hyperactivation. The AR is a modified exocytotic event involving the acrosome and the overlying sperm plasma membrane (Yudin et al. 1988, Yanagimachi 1994). The AR is required for penetration of the zona pellucida (ZP) of the egg and for sperm-egg plasma membrane fusion. Hyperactivation is a specialized movement of the sperm flagellum creating a propulsive force for passing through the ZP. Hyperactivated spermatozoa exhibit a large bend amplitude, whiplash and frenzied flagellar movements (Yanagimachi 1994, Fujinoki et al. 2001a, Suarez \& Ho 2003).

Albumin, calcium and bicarbonate are important molecules in the capacitation process. Albumin promotes capacitation by removing cholesterol from the sperm plasma membrane (Langlais \& Roberts 1985). Calcium and bicarbonate are involved in several intracellular signals such as the stimulation of adenylate cyclase, production of cAMP, and protein phosphorylation (Okamura et al. 1985, Visconti \& Kopf 1998,
Visconti et al. 1998, Ho \& Suarez 2001, Ho et al. 2002). For protein phosphorylations, it has been suggested that tyrosine phosphorylations are closely associated with capacitation (Visconti et al. 1995, Fujinoki et al. 2001b, 2006, Jha \& Shivaji 2001). Moreover, 80 and/or 85 kDa tyrosine phosphorylations are regulated by calcium/ calmodulin-dependent signals (Carrera et al. 1996) and protein phosphatase 1 (Suzuki et al. 2010), and are identified as A-kinase anchoring protein (AKAP; Carrera et al. 1996, Jha \& Shivaji 2002).

Progesterone isolated from follicular fluid is a stimulator of human sperm AR (Osman et al. 1989). Progesterone stimulates the AR via non-genomic regulation (Baldi et al. 1998, 2009, Lösel \& Wehling 2003, Luconi et al. 2004). In human spermatozoa, progesterone stimulates calcium influx, tyrosine phosphorylation, chloride efflux, and cAMP increase (Lösel \& Wehling 2003, Harper et al. 2004, Luconi et al. 2004, Baldi et al. 2009). It also stimulates ZP penetration and the AR in hamster spermatozoa (Libersky \& Boatman 1995b, Llanos \& Anabalon 1996). Although spermatozoa do not have a classic intracellular progesterone receptor (PGR), a PGR is present in the cell membrane 
(Sabeur et al. 1996, Baldi et al. 1998, 2009, Lösel \& Wehling 2003, Luconi et al. 2004, Jang \& Yi 2005). Moreover, it has been suggested that progesterone binds to the acrosome region, and PGR is localized to the same region in human (Gadkar et al. 2002) and hamster spermatozoa (Noguchi et al. 2008). Phospholipase C (PLC; Fukami et al. 2003) and/or protein kinase A (Harrison et al. 2000) are involved in progesteroneinduced AR. Progesterone also changes motility parameters (Yang et al. 1994) and enhances hyperactivation in human (Sueldo et al. 1993) and hamster spermatozoa (Noguchi et al. 2008). Although progesterone enhances hyperactivation of human and hamster spermatozoa (Sueldo et al. 1993, Noguchi et al. 2008), the effective concentration of progesterone is different between humans and hamsters. For human spermatozoa, the effective concentration of progesterone for the enhancement of hyperactivation was several micrograms per milliliter, the same as the effective concentration for inducing the AR (Osman et al. 1989, Sueldo et al. 1993). On the other hand, for hamster spermatozoa, the effective concentration of progesterone for the enhancement of hyperactivation was $20 \mathrm{ng} / \mathrm{ml}$ (Noguchi et al. 2008). Moreover, at a concentration of $20 \mathrm{ng} / \mathrm{ml}$, progesterone increased hamster sperm penetration and did not induce hamster sperm AR (Libersky \& Boatman 1995b). At a concentration of $20 \mathrm{ng} / \mathrm{ml}$, progesterone also enhanced and increased tyrosine phosphorylations associated with hyperactivation of hamster spermatozoa (Noguchi et al. 2008). The effective progesterone concentration for hamster sperm AR was also several micrograms per milliliter (Libersky \& Boatman 1995b). Libersky \& Boatman (1995a) measured progesterone concentration in fluids of reproductive organs, reporting that the progesterone concentration in hamster serum ranged from 5.56 to $12.85 \mathrm{ng} / \mathrm{ml}$, the follicular fluid concentration ranged from 4.2 to $7.4 \mu \mathrm{g} / \mathrm{ml}$, and the oviductal fluid concentration ranged from 44.04 to $175.06 \mathrm{ng} / \mathrm{ml}$.

It has been suggested that $17 \beta$-estradiol $\left(17 \beta \mathrm{E}_{2}\right)$ is also associated with a regulation of the AR (Luconi et al. 1999, 2004, Baldi et al. 2000, 2009). In human spermatozoa, $17 \beta \mathrm{E}_{2}$ stimulates calcium influx and suppresses progesterone-induced AR (Luconi et al. 1999, Baldi et al. 2000). Estrogen receptors (ESRs) are also present in the cell membrane (Luconi et al. 1999, 2004, Baldi et al. 2000, 2009). Moreover, the suppression of progesterone-induced $\mathrm{AR}$ by $17 \beta \mathrm{E}_{2}$ is non-genomic (Luconi et al. 2004, Baldi et al. 2009).

Although the $A R$ is regulated by estrogen $\left(E_{2}\right)$ and progesterone via non-genomic regulation, it is not known whether progesterone-enhanced hyperactivation is suppressed by $17 \beta \mathrm{E}_{2}$. In the present study, I have shown that progesterone-enhanced hyperactivation and tyrosine phosphorylations are suppressed by $17 \beta \mathrm{E}_{2}$ via non-genomic regulation.

\section{Results}

\section{Suppression of progesterone-enhanced hyperactivation by $17 \beta E_{2}$}

An earlier study suggested that hamster sperm hyperactivation was enhanced by $20 \mathrm{ng} / \mathrm{ml}$ progesterone via non-genomic regulation (Noguchi et al. 2008). It has been suggested that the AR is induced by progesterone and suppressed by $17 \beta \mathrm{E}_{2}$ (Luconi et al. 1999, 2004, Baldi et al. 2000, 2009), so I examined whether hyperactivation was also enhanced by progesterone and suppressed by $17 \beta \mathrm{E}_{2}$ using hamster spermatozoa.

Although $17 \beta \mathrm{E}_{2}$ itself did not affect the percentage of motile spermatozoa and hyperactivation in hamster spermatozoa at all (Fig. 1), it affected progesteroneenhanced hyperactivation in a concentration-dependent manner (Figs 2 and 3). As shown in Fig. 2A and B, $17 \beta \mathrm{E}_{2}$ suppressed progesterone-enhanced hyperactivation in a concentration-dependent manner, although it did not affect the percentage of motile spermatozoa when spermatozoa were exposed to $20 \mathrm{ng} / \mathrm{ml}$ progesterone after exposure to $20 \mathrm{ng} / \mathrm{ml}$ down to $2 \mathrm{fg} / \mathrm{ml}$ $17 \beta \mathrm{E}_{2}$. When incubated for 1 (Fig. 2C), 1.5 (Fig. 2D), and $2 \mathrm{~h}$ (Fig. 2E), progesterone-enhanced hyperactivation was significantly suppressed by $20 \mathrm{ng} / \mathrm{ml}, 2 \mathrm{ng} / \mathrm{ml}$, and $200 \mathrm{pg} / \mathrm{ml} 17 \beta \mathrm{E}_{2}$ respectively. On the other hand, no suppression of progesterone-enhanced hyperactivation was observed at a concentration from $2 \mathrm{pg} / \mathrm{ml}$ down
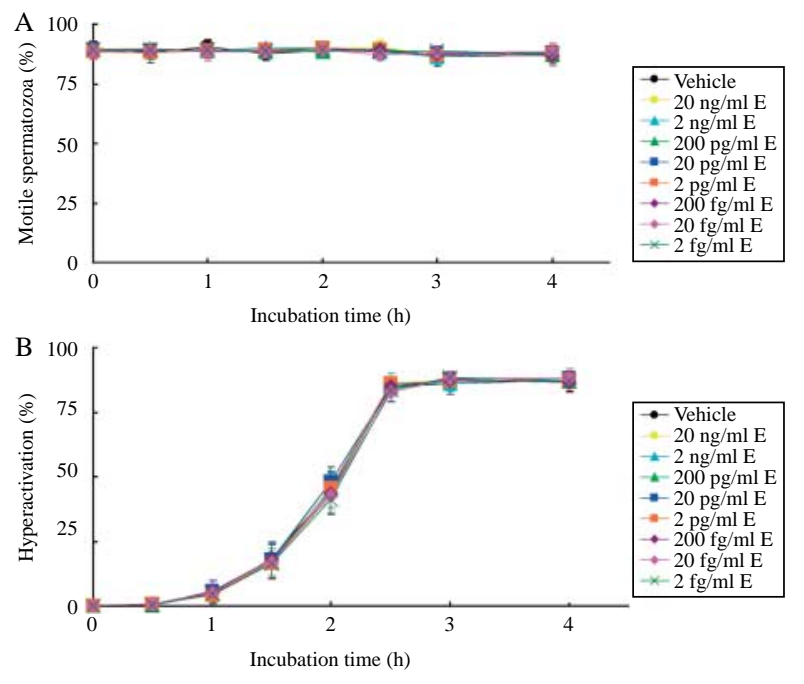

Figure 1 Effects of $17 \beta \mathrm{E}_{2}$ on the percentage of motile spermatozoa and hyperactivation. The percentage of motile spermatozoa $(A)$ and hyperactivation $(\mathrm{B})$ are shown when $17 \beta \mathrm{E}_{2}$ was added to mTALP medium. Data are expressed as mean \pm s.D. (Vehicle), $\mathrm{mTALP}+0.1 \%(\mathrm{v} / \mathrm{v}) \mathrm{EtOH}$; $(20 \mathrm{ng} / \mathrm{ml} \mathrm{E}), \mathrm{mTALP}+20 \mathrm{ng} / \mathrm{ml} 17 \beta \mathrm{E}_{2}+0.1 \%$ (v/v) EtOH; $(2 \mathrm{ng} / \mathrm{ml} \mathrm{E})$, $\mathrm{mTALP}+2 \mathrm{ng} / \mathrm{ml} 17 \beta \mathrm{E}_{2}+0.1 \%(\mathrm{v} / \mathrm{v}) \mathrm{EtOH} ;(200 \mathrm{pg} / \mathrm{ml} \mathrm{E}), \mathrm{mTALP}+$ $200 \mathrm{pg} / \mathrm{ml} 17 \beta \mathrm{E}_{2}+0.1 \%(\mathrm{v} / \mathrm{v}) \mathrm{EtOH} ;(20 \mathrm{pg} / \mathrm{ml} \mathrm{E}), \mathrm{mTALP}+20 \mathrm{pg} / \mathrm{ml}$ $17 \beta \mathrm{E}_{2}+0.1 \%(\mathrm{v} / \mathrm{v}) \mathrm{EtOH} ;(2 \mathrm{pg} / \mathrm{ml} \mathrm{E}), \mathrm{mTALP}+2 \mathrm{pg} / \mathrm{ml} 17 \beta \mathrm{E}_{2}+0.1 \%$ (v/v) EtOH; (200 fg/ml E), mTALP+200 fg/ml 17 $3 \mathrm{E}_{2}+0.1 \%(\mathrm{v} / \mathrm{v}) \mathrm{EtOH}$; $(20 \mathrm{fg} / \mathrm{ml} \mathrm{E}), \mathrm{mTALP}+20 \mathrm{fg} / \mathrm{ml} 17 \beta \mathrm{E}_{2}+0.1 \%(\mathrm{v} / \mathrm{v}) \mathrm{EtOH} ;(2 \mathrm{fg} / \mathrm{ml} \mathrm{E})$, $\mathrm{mTALP}+2 \mathrm{fg} / \mathrm{ml} 17 \beta \mathrm{E}_{2}+0.1 \%(\mathrm{v} / \mathrm{v}) \mathrm{EtOH}$. 

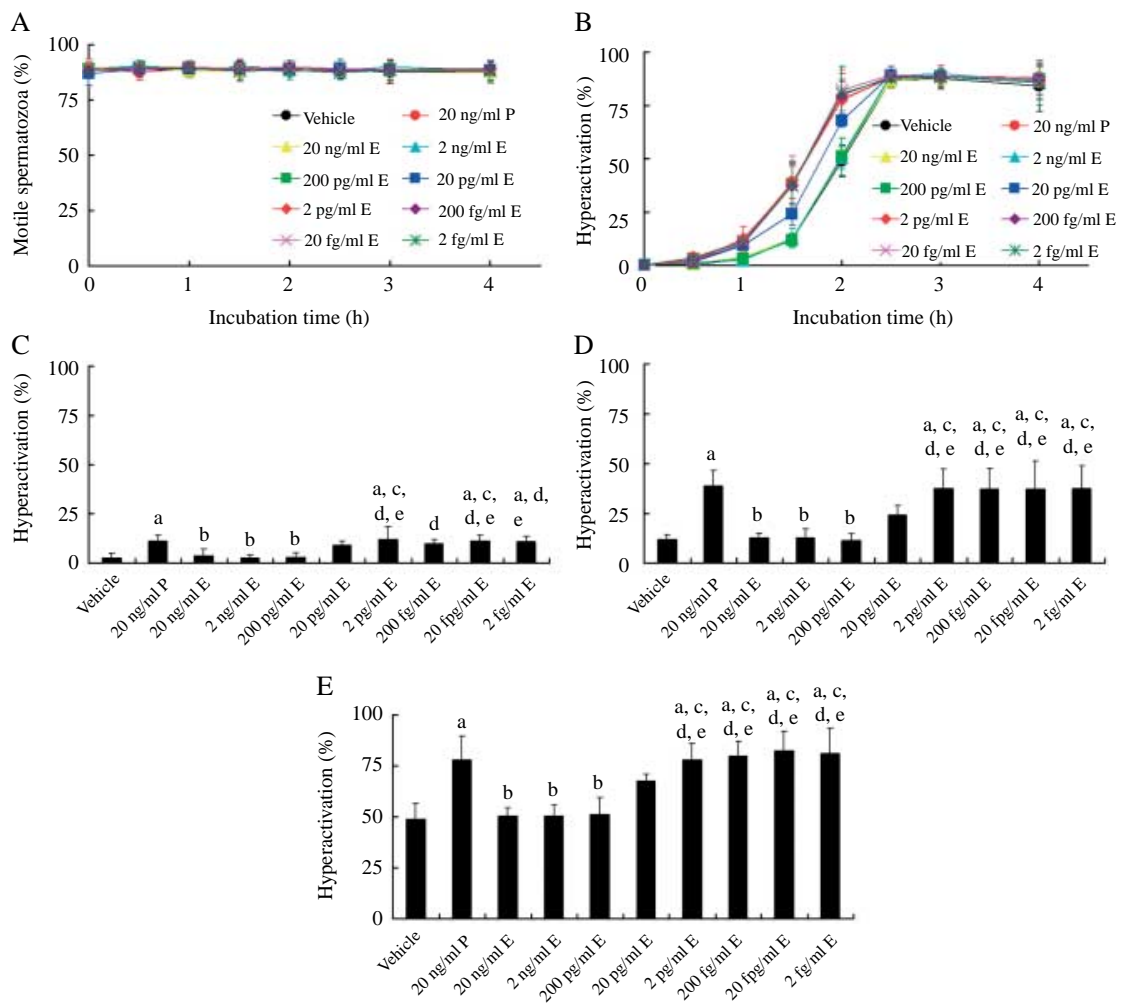

Figure $2 \mathrm{Effects}$ of $17 \mathrm{E}_{2}$ on the percentage of motile spermatozoa and progesterone-enhanced hyperactivation when spermatozoa were exposed to $20 \mathrm{ng} / \mathrm{ml}$ progesterone after exposure to $17 \beta \mathrm{E}_{2}$ for $5 \mathrm{~min}$. The percentage of motile spermatozoa is shown as an overview of effects (A) when $17 \beta \mathrm{E}_{2}$ and progesterone were added to mTALP medium. The percentage of hyperactivation is shown as an overview of effects (B) and after incubation for 1 (C), 1.5 (D), and 2 (E) $\mathrm{h}$ after progesterone was added to the mTALP medium. Data are expressed as mean \pm s.D. (Vehicle), $\mathrm{mTALP}+0.2 \%(\mathrm{v} / \mathrm{v}) \mathrm{EtOH} ;(20 \mathrm{ng} / \mathrm{ml}$ progesterone $), \mathrm{mTALP}+20 \mathrm{ng} / \mathrm{ml}$ progesterone $+0.2 \%(\mathrm{v} / \mathrm{v}) \mathrm{EtOH} ;(20 \mathrm{ng} / \mathrm{ml} \mathrm{E}), \mathrm{mTALP}+20 \mathrm{ng} / \mathrm{ml}$ $17 \beta \mathrm{E}_{2}+20 \mathrm{ng} / \mathrm{ml}$ progesterone $+0.2 \%(\mathrm{v} / \mathrm{v}) \mathrm{EtOH} ;(2 \mathrm{ng} / \mathrm{ml} \mathrm{E}), \mathrm{mTALP}+2 \mathrm{ng} / \mathrm{ml} 17 \beta \mathrm{E}_{2}+20 \mathrm{ng} / \mathrm{ml}$ progesterone $+0.2 \%(\mathrm{v} / \mathrm{v}) \mathrm{EtOH} ;(200 \mathrm{pg} / \mathrm{ml} \mathrm{E})$, $\mathrm{mTALP}+200 \mathrm{pg} / \mathrm{ml} 17 \beta \mathrm{E}_{2}+20 \mathrm{ng} / \mathrm{ml}$ progesterone $+0.2 \%(\mathrm{v} / \mathrm{v}) \mathrm{EtOH} ;(20 \mathrm{pg} / \mathrm{ml} \mathrm{E}), \mathrm{mTALP}+20 \mathrm{pg} / \mathrm{ml} 17 \beta \mathrm{E}_{2}+20 \mathrm{ng} / \mathrm{ml}$ progesterone $+0.2 \%$ $(\mathrm{v} / \mathrm{v}) \mathrm{EtOH} ;(2 \mathrm{pg} / \mathrm{ml} \mathrm{E}), \mathrm{mTALP}+2 \mathrm{pg} / \mathrm{ml} 17 \beta \mathrm{E}_{2}+20 \mathrm{ng} / \mathrm{ml}$ progesterone $+0.2 \%(\mathrm{v} / \mathrm{v}) \mathrm{EtOH} ;(200 \mathrm{fg} / \mathrm{ml} \mathrm{E}), \mathrm{mTALP}+200 \mathrm{fg} / \mathrm{ml} 17 \beta \mathrm{E}_{2}+20 \mathrm{ng} / \mathrm{ml}$ progesterone $+0.2 \%(\mathrm{v} / \mathrm{v}) \mathrm{EtOH} ;(20 \mathrm{fg} / \mathrm{ml} \mathrm{E}), \mathrm{mTALP}+20 \mathrm{fg} / \mathrm{ml} 17 \beta \mathrm{E}_{2}+20 \mathrm{ng} / \mathrm{ml}$ progesterone $+0.2 \%(\mathrm{v} / \mathrm{v}) \mathrm{EtOH} ;(2 \mathrm{fg} / \mathrm{ml} \mathrm{E}), \mathrm{mTALP}+2 \mathrm{fg} / \mathrm{ml}$ $17 \beta \mathrm{E}_{2}+20 \mathrm{ng} / \mathrm{ml}$ progesterone $+0.2 \%(\mathrm{v} / \mathrm{v}) \mathrm{EtOH}$. ${ }^{\mathrm{a} S}$ Significant difference compared with vehicle $(P<0.05)$; ${ }^{\mathrm{b}}$ Significant difference compared with $20 \mathrm{ng} / \mathrm{ml}$ progesterone $(P<0.05)$; ${ }^{\mathrm{c}}$ Significant difference compared with $20 \mathrm{ng} / \mathrm{ml} \mathrm{E}(P<0.05)$; ${ }^{\mathrm{d}}$ Significant difference compared with $2 \mathrm{ng} / \mathrm{ml}$ $\mathrm{E}(P<0.05)$. ${ }^{\mathrm{e}}$ Significant difference compared with $200 \mathrm{pg} / \mathrm{ml} \mathrm{E}(P<0.05)$.

to $2 \mathrm{fg} / \mathrm{ml} 17 \beta \mathrm{E}_{2}$. Interestingly, the suppression of progesterone-enhanced hyperactivation by $20 \mathrm{pg} / \mathrm{ml}$ $17 \beta \mathrm{E}_{2}$ was midway between progesterone-enhanced hyperactivation and vehicle alone, with no significant difference to either. When spermatozoa were exposed to $20 \mathrm{ng} / \mathrm{ml}$ to $2 \mathrm{fg} / \mathrm{ml} 17 \beta \mathrm{E}_{2}$ and $20 \mathrm{ng} / \mathrm{ml}$ progesterone at the same time, $17 \beta \mathrm{E}_{2}$ suppressed progesterone-enhanced hyperactivation in a concentration-dependent manner, although it did not affect the percentage of motile spermatozoa (Fig. $3 \mathrm{~A}$ and B). When incubated for 1 (Fig. 3C), 1.5 (Fig. 3D), and $2 \mathrm{~h}$ (Fig. 3E), 20 and $2 \mathrm{ng} / \mathrm{ml}$ $17 \beta \mathrm{E}_{2}$ significantly suppressed progesterone-enhanced hyperactivation. In contrast, $2 \mathrm{pg} / \mathrm{ml}$ to $1 \mathrm{fg} / \mathrm{ml} 17 \beta \mathrm{E}_{2}$ did not suppress progesterone-enhanced hyperactivation. When incubated for $1 \mathrm{~h}$ (Fig. 3C), the suppression of progesterone-enhanced hyperactivation by 200 and $20 \mathrm{pg} / \mathrm{ml} 17 \beta \mathrm{E}_{2}$ was midway between progesteroneenhanced hyperactivation and vehicle alone, with no significant difference to either. When incubated for $1.5 \mathrm{~h}$
(Fig. 3D), the suppression of progesterone-enhanced hyperactivation by $200 \mathrm{pg} / \mathrm{ml} 17 \beta \mathrm{E}_{2}$ was midway between progesterone-enhanced hyperactivation and vehicle alone, with a significant difference to both. However, $20 \mathrm{pg} / \mathrm{ml} 17 \beta \mathrm{E}_{2}$ did not suppress progesteroneenhanced hyperactivation. When incubated for $2 \mathrm{~h}$ (Fig. 3E), $200 \mathrm{pg} / \mathrm{ml} 17 \beta \mathrm{E}_{2}$ significantly suppressed progesterone-enhanced hyperactivation, but $20 \mathrm{pg} / \mathrm{ml}$ $17 \beta \mathrm{E}_{2}$ had no effect. When spermatozoa were exposed to $20 \mathrm{ng} / \mathrm{ml}$ to $2 \mathrm{fg} / \mathrm{ml} 17 \beta \mathrm{E}_{2}$ after exposure to $20 \mathrm{ng} / \mathrm{ml}$ progesterone, $17 \beta \mathrm{E}_{2}$ did not affect the percentage of motile spermatozoa or progesterone-enhanced hyperactivation at all (Fig. 4).

The two isomers of $E_{2}$ are $17 \alpha$-estradiol $\left(17 \alpha \mathrm{E}_{2}\right)$ and $17 \beta \mathrm{E}_{2}$, of which $17 \beta \mathrm{E}_{2}$ alone has biological activity. When spermatozoa were exposed to $20 \mathrm{ng} / \mathrm{ml}$ progesterone after exposure to $20 \mathrm{ng} / \mathrm{ml}$ to $200 \mathrm{pg} / \mathrm{ml}$ $17 \alpha \mathrm{E}_{2}, 17 \alpha \mathrm{E}_{2}$ had no effect on the percentage of motile spermatozoa or progesterone-enhanced hyperactivation 

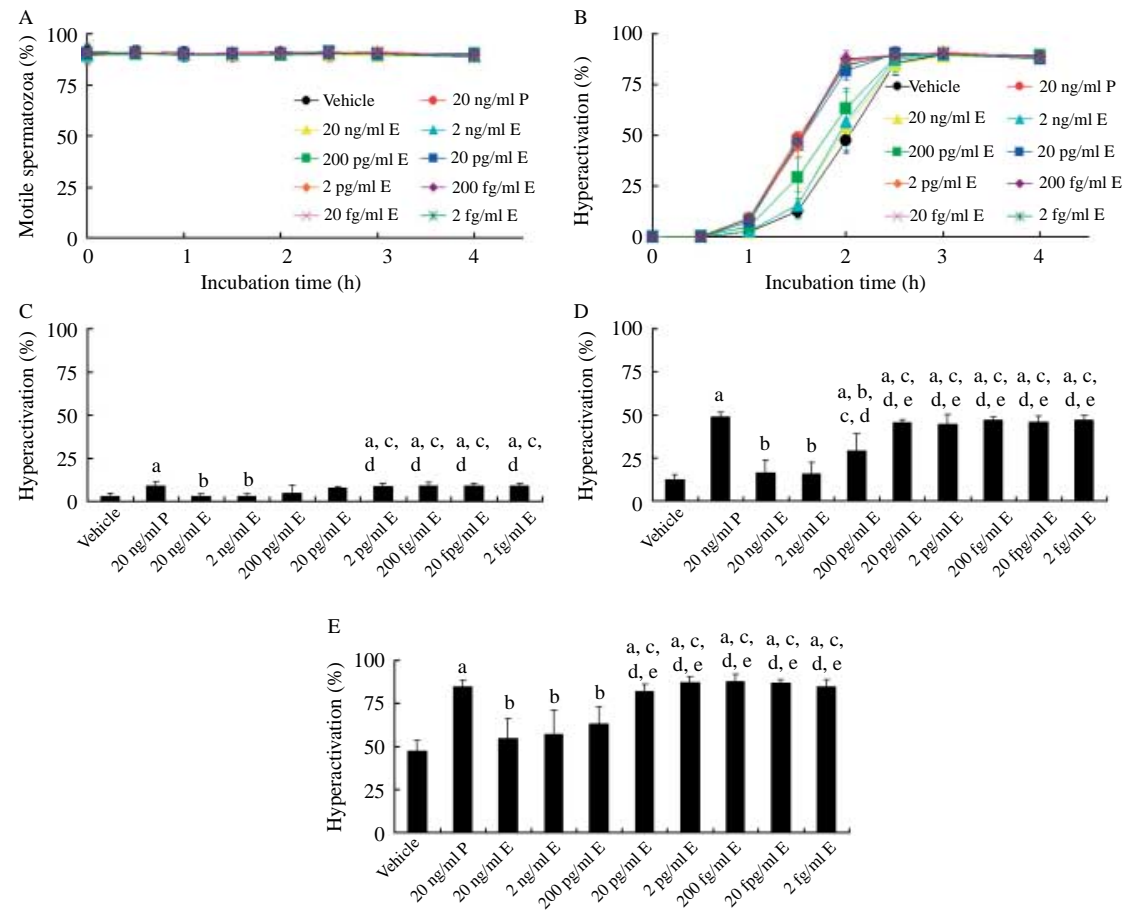

Figure $3 \mathrm{Effects}$ of $17 \beta \mathrm{E}_{2}$ on the percentage of motile spermatozoa and progesterone-enhanced hyperactivation when spermatozoa were exposed to $17 \beta \mathrm{E}_{2}$ and $20 \mathrm{ng} / \mathrm{ml}$ progesterone at the same time. The percentage of motile spermatozoa is shown as an overview of effects $(\mathrm{A})$ when $17 \beta \mathrm{E}_{2}$ and progesterone were added to mTALP medium. The percentage of hyperactivation is shown as an overview of effects (B) and after incubation for 1 (C), 1.5 (D), and 2 (E) h after progesterone was added to the mTALP medium. Data are expressed as mean \pm s.D. (Vehicle), $\mathrm{mTALP}+0.2 \%(\mathrm{v} / \mathrm{v})$ $\mathrm{EtOH} ;\left(20 \mathrm{ng} / \mathrm{ml}\right.$ progesterone), $\mathrm{mTALP}+20 \mathrm{ng} / \mathrm{ml}$ progesterone $+0.2 \%(\mathrm{v} / \mathrm{v}) \mathrm{EtOH} ;(20 \mathrm{ng} / \mathrm{ml} \mathrm{E}), \mathrm{mTALP}+20 \mathrm{ng} / \mathrm{ml} 17 \beta \mathrm{E}_{2}+20 \mathrm{ng} / \mathrm{ml}$ progesterone $+0.2 \%(\mathrm{v} / \mathrm{v}) \mathrm{EtOH} ;(2 \mathrm{ng} / \mathrm{ml} \mathrm{E}), \mathrm{mTALP}+2 \mathrm{ng} / \mathrm{ml} 17 \beta \mathrm{E}_{2}+20 \mathrm{ng} / \mathrm{ml}$ progesterone $+0.2 \%(\mathrm{v} / \mathrm{v}) \mathrm{EtOH} ;(200 \mathrm{pg} / \mathrm{ml} \mathrm{E}), \mathrm{mTALP}+200 \mathrm{pg} / \mathrm{ml}$ $17 \beta \mathrm{E}_{2}+20 \mathrm{ng} / \mathrm{ml}$ progesterone $+0.2 \%(\mathrm{v} / \mathrm{v}) \mathrm{EtOH} ;(20 \mathrm{pg} / \mathrm{ml} \mathrm{E}), \mathrm{mTALP}+20 \mathrm{pg} / \mathrm{ml} 17 \beta \mathrm{E}_{2}+20 \mathrm{ng} / \mathrm{ml}$ progesterone $+0.2 \%(\mathrm{v} / \mathrm{v}) \mathrm{EtOH} ;(2 \mathrm{pg} / \mathrm{ml} \mathrm{E})$, $\mathrm{mTALP}+2 \mathrm{pg} / \mathrm{ml} 17 \beta \mathrm{E}_{2}+20 \mathrm{ng} / \mathrm{ml}$ progesterone $+0.2 \%(\mathrm{v} / \mathrm{v}) \mathrm{EtOH} ;(200 \mathrm{fg} / \mathrm{ml} \mathrm{E}), \mathrm{mTALP}+200 \mathrm{fg} / \mathrm{ml} 17 \beta \mathrm{E}_{2}+20 \mathrm{ng} / \mathrm{ml} \mathrm{progesterone}+0.2 \%(\mathrm{v} / \mathrm{v})$ $\mathrm{EtOH} ;(20 \mathrm{fg} / \mathrm{ml} \mathrm{E}), \mathrm{mTALP}+20 \mathrm{fg} / \mathrm{ml} 17 \beta \mathrm{E}_{2}+20 \mathrm{ng} / \mathrm{ml}$ progesterone $+0.2 \%(\mathrm{v} / \mathrm{v}) \mathrm{EtOH} ;(2 \mathrm{fg} / \mathrm{ml} \mathrm{E}), \mathrm{mTALP}+2 \mathrm{fg} / \mathrm{ml} 17 \beta \mathrm{E}_{2}+20 \mathrm{ng} / \mathrm{ml}$ progesterone $+0.2 \%(\mathrm{v} / \mathrm{v})$ EtOH. ${ }^{\mathrm{a}}$ Significant difference compared with vehicle $(P<0.05)$; ${ }^{\mathrm{b}}$ Significant difference compared with $20 \mathrm{ng} / \mathrm{ml}$ progesterone $(P<0.05)$; ${ }^{C}$ Significant difference compared with $20 \mathrm{ng} / \mathrm{ml} \mathrm{E}(P<0.05)$; ${ }^{\mathrm{d}}$ Significant difference compared with $2 \mathrm{ng} / \mathrm{ml} \mathrm{E}(P<0.05)$. eSignificant difference compared with $200 \mathrm{pg} / \mathrm{ml} \mathrm{E}(P<0.05)$.

(Fig. 5), whereas $20 \mathrm{ng} / \mathrm{ml}$ to $200 \mathrm{pg} / \mathrm{ml} 17 \beta \mathrm{E}_{2}$ suppressed progesterone-enhanced hyperactivation (Fig. 2B).

In general, $17 \beta \mathrm{E}_{2}$ affects cell functions via ESRs. Tamoxifen is an inhibitor of ESRs and was added to the modified Tyrode's albumin lactate pyruvate (mTALP) medium before $17 \beta \mathrm{E}_{2}$ and/or progesterone were added to mTALP medium. When spermatozoa were exposed to $1 \mu \mathrm{mol} / \mathrm{l}$ tamoxifen before exposure to $20 \mathrm{ng} / \mathrm{ml}$ progesterone, tamoxifen had no effect on the percentage of motile spermatozoa, hyperactivation, or progesteroneenhanced hyperactivation (Fig. 6A and B). As shown in Figs 2 and $6 \mathrm{D}, 17 \beta \mathrm{E}_{2}$ suppressed progesterone-enhanced hyperactivation when spermatozoa were exposed to $20 \mathrm{ng} / \mathrm{ml} 17 \beta \mathrm{E}_{2}$ before exposure to $20 \mathrm{ng} / \mathrm{ml}$ progesterone. However, the suppression of progesteroneenhanced hyperactivation by $17 \beta \mathrm{E}_{2}$ was significantly inhibited by tamoxifen when spermatozoa were exposed to $1 \mu \mathrm{mol} / \mathrm{l}$ tamoxifen before exposure to $20 \mathrm{ng} / \mathrm{ml} 17 \beta \mathrm{E}_{2}$ and $20 \mathrm{ng} / \mathrm{ml}$ progesterone (Fig. 6D). Under the same condition (Fig. 6C), tamoxifen had no effect on the percentage of motile spermatozoa.

\section{Suppression of progesterone-enhanced hyperactivation by $17 \beta E_{2}$ via non-genomic regulation}

Sperm hyperactivation is enhanced by progesterone via non-genomic regulation associated with PGR (Noguchi et al. 2008). In the next step, I used FITC/BSA-17ß $\mathrm{E}_{2}$ to determine whether hamster sperm hyperactivation was regulated by $17 \beta \mathrm{E}_{2}$ via non-genomic regulation. Generally, $17 \beta \mathrm{E}_{2}$ enters the cell, binds to the intracellular ESRs, and induces gene expression (Baldi et al. 1998, 2009, Lösel \& Wehling 2003, Luconi et al. 2004). However, FITC/BSA-17 $\beta \mathrm{E}_{2}$ cannot enter the cell because BSA blocks the entry of $17 \beta \mathrm{E}_{2}$ into the cell. It follows that the effects of FITC/BSA- $17 \beta \mathrm{E}_{2}$ occur through non-genomic signals.

As shown in Fig. $7 \mathrm{~A}$ and $\mathrm{B}, 7.4 \mathrm{nmol} / \mathrm{l}, 740 \mathrm{pmol} / \mathrm{l}$, and $74 \mathrm{pmol} / \mathrm{I}$ FITC/BSA-17 $\beta \mathrm{E}_{2}$, which are converted into $\sim 20 \mathrm{ng} / \mathrm{ml}, 2 \mathrm{ng} / \mathrm{ml}$, and $200 \mathrm{pg} / \mathrm{ml} 17 \beta \mathrm{E}_{2}$ respectively did not affect the percentage of motile spermatozoa and hyperactivation, as with $17 \beta \mathrm{E}_{2}$ (Fig. 1). When spermatozoa were exposed to $20 \mathrm{ng} / \mathrm{ml}$ progesterone after exposure to $7.4 \mathrm{nmol} / \mathrm{l}, 740 \mathrm{pmol} / \mathrm{l}$, and $74 \mathrm{pmol} / \mathrm{l}$ 


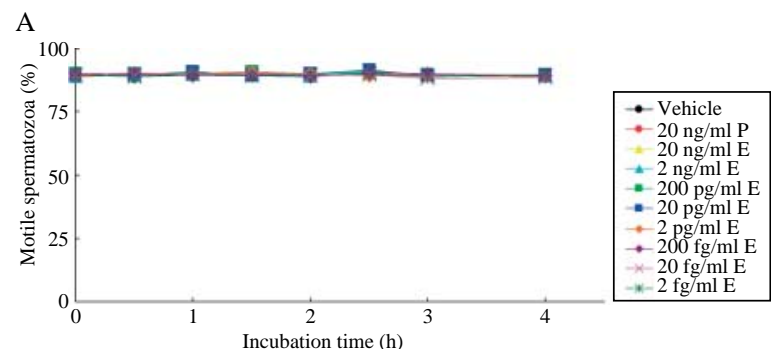

B

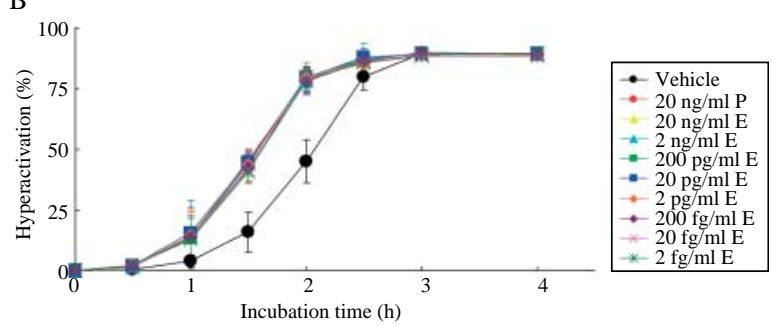

Figure 4 Effects of $17 \beta \mathrm{E}_{2}$ on the percentage of motile spermatozoa and progesterone-enhanced hyperactivation when spermatozoa were exposed to $17 \beta \mathrm{E}_{2}$ after exposure to $20 \mathrm{ng} / \mathrm{ml}$ progesterone for $5 \mathrm{~min}$. The percentage of motile spermatozoa (A) and hyperactivation (B) are shown when $17 \mathrm{E}_{2}$ and progesterone were added to mTALP medium. Data are expressed as mean \pm s.D. (Vehicle), $\mathrm{mTALP}+0.2 \%(\mathrm{v} / \mathrm{v})$ $\mathrm{EtOH} ;(20 \mathrm{ng} / \mathrm{ml}$ progesterone), $\mathrm{mTALP}+20 \mathrm{ng} / \mathrm{ml}$ progesterone $+0.2 \%(\mathrm{v} / \mathrm{v}) \mathrm{EtOH} ;(20 \mathrm{ng} / \mathrm{ml} \mathrm{E}), \mathrm{mTALP}+20 \mathrm{ng} / \mathrm{ml} 17 \beta \mathrm{E}_{2}+20 \mathrm{ng} / \mathrm{ml}$ progesterone $+0.2 \%(\mathrm{v} / \mathrm{v}) \mathrm{EtOH} ;(2 \mathrm{ng} / \mathrm{ml} \mathrm{E}), \mathrm{mTALP}+2 \mathrm{ng} / \mathrm{ml}$ $17 \beta \mathrm{E}_{2}+20 \mathrm{ng} / \mathrm{ml}$ progesterone $+0.2 \%(\mathrm{v} / \mathrm{v}) \mathrm{EtOH} ;(200 \mathrm{pg} / \mathrm{ml} \mathrm{E})$, $\mathrm{mTALP}+200 \mathrm{pg} / \mathrm{ml} 17 \beta \mathrm{E}_{2}+20 \mathrm{ng} / \mathrm{ml}$ progesterone $+0.2 \%(\mathrm{v} / \mathrm{v})$ $\mathrm{EtOH} ;(20 \mathrm{pg} / \mathrm{ml} \mathrm{E}), \mathrm{mTALP}+20 \mathrm{pg} / \mathrm{ml} 17 \beta \mathrm{E}_{2}+20 \mathrm{ng} / \mathrm{ml}$ progesterone $+0.2 \%(\mathrm{v} / \mathrm{v}) \mathrm{EtOH} ;(2 \mathrm{pg} / \mathrm{ml} \mathrm{E}), \mathrm{mTALP}+2 \mathrm{pg} / \mathrm{ml} 17 \beta \mathrm{E}_{2}$ $+20 \mathrm{ng} / \mathrm{ml}$ progesterone $+0.2 \%(\mathrm{v} / \mathrm{v}) \mathrm{EtOH} ;(200 \mathrm{fg} / \mathrm{ml} \mathrm{E}), \mathrm{mTALP}$ $+200 \mathrm{fg} / \mathrm{ml} 17 \beta \mathrm{E}_{2}+20 \mathrm{ng} / \mathrm{ml}$ progesterone $+0.2 \%(\mathrm{v} / \mathrm{v}) \mathrm{EtOH}$; $(20 \mathrm{fg} / \mathrm{ml} \mathrm{E}), \mathrm{mTALP}+20 \mathrm{fg} / \mathrm{ml} 17 \beta \mathrm{E}_{2}+20 \mathrm{ng} / \mathrm{ml}$ progesterone $+0.2 \%$ (v/v) $\mathrm{EtOH} ;(2 \mathrm{fg} / \mathrm{ml} \mathrm{E}), \mathrm{mTALP}+2 \mathrm{fg} / \mathrm{ml} 17 \mathrm{E}_{2}+20 \mathrm{ng} / \mathrm{ml}$ progesterone $+0.2 \%(\mathrm{v} / \mathrm{v}) \mathrm{EtOH}$. All spermatozoa exposed to progesterone showed significant enhancement of hyperactivation compared with vehicle $(P<0.05)$. progesterone-enhanced hyperactivation was unaffected by $17 \beta \mathrm{E}_{2}$.

FITC/BSA-17 $\beta \mathrm{E}_{2}$, progesterone-enhanced hyperactivation was significantly suppressed by $7.4 \mathrm{nmol} / \mathrm{l}, 740 \mathrm{pmol} / \mathrm{l}$, and $74 \mathrm{pmol} / \mathrm{I} \mathrm{FITC} / \mathrm{BSA}-17 \beta \mathrm{E}_{2}$, although they did not affect the percentage of motile spermatozoa (Fig. 7C and $\mathrm{D})$. The suppression of progesterone-enhanced hyperactivation by $7.4 \mathrm{nmol} / \mathrm{l}$ FITC/BSA- $17 \beta \mathrm{E}_{2}$ was significantly inhibited by $1 \mu \mathrm{mol} / \mathrm{l}$ tamoxifen, although tamoxifen did not affect the percentage of motile spermatozoa (Fig. 7E and F).

\section{Binding of $17 \beta E_{2}$ to hamster spermatozoa}

Progesterone binds to the acrosome region of the sperm head (Gadkar et al. 2002, Noguchi et al. 2008; Fig. 8Ac and $\mathrm{Ad}$ ), although fluorescence of the middle piece of the sperm flagellum appears to be autofluorescence (Noguchi et al. 2008; Fig. 8Aa and Ab). As shown in Fig. $8 \mathrm{Ae}-\mathrm{h}$, it was observed that $7.4 \mathrm{nmol} / \mathrm{l}$
FITC/BSA-17 $\beta \mathrm{E}_{2}$ bound to the acrosome region of the sperm head. Interestingly, $1 \mu \mathrm{mol} / \mathrm{l}$ tamoxifen did not inhibit the binding of FITC/BSA-17 $\beta \mathrm{E}_{2}$ to the sperm head (Fig. 8B), although it did inhibit the effects of $17 \beta \mathrm{E}_{2}$ and FITC/BSA- $17 \beta E_{2}$ on progesterone-enhanced hyperactivation (Figs 6 and 7).

When spermatozoa were exposed to $20 \mathrm{ng} / \mathrm{ml} 17 \beta \mathrm{E}_{2}$ before exposure to $20 \mathrm{ng} / \mathrm{ml}$ progesterone, progesteroneenhanced hyperactivation was suppressed by $17 \beta \mathrm{E}_{2}$ (Fig. 2). However, binding of $7 \mathrm{nmol} / \mathrm{l}$ FITC/BSA-P, converted $\sim 20 \mathrm{ng} / \mathrm{ml}$ progesterone, to the hamster sperm head was not inhibited by $20 \mathrm{ng} / \mathrm{ml} 17 \beta \mathrm{E}_{2}$ when spermatozoa were exposed to $20 \mathrm{ng} / \mathrm{ml} 17 \beta \mathrm{E}_{2}$ before exposure to $7 \mathrm{nmol} / \mathrm{I} \mathrm{FITC/BSA-P}$ (Fig. 8Ca-d). On the other hand, progesterone-enhanced hyperactivation was not suppressed by $17 \beta \mathrm{E}_{2}$ when spermatozoa were exposed to $20 \mathrm{ng} / \mathrm{ml} 17 \beta \mathrm{E}_{2}$ after exposure to $20 \mathrm{ng} / \mathrm{ml}$ progesterone (Fig. 4). Binding of $7.4 \mathrm{nmol} / \mathrm{l}$ FITC/BSA$17 \beta \mathrm{E}_{2}$ to the sperm head was not suppressed by $20 \mathrm{ng} / \mathrm{ml}$ progesterone when spermatozoa were exposed to

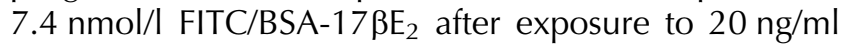
progesterone (Fig. 8Ce-h).
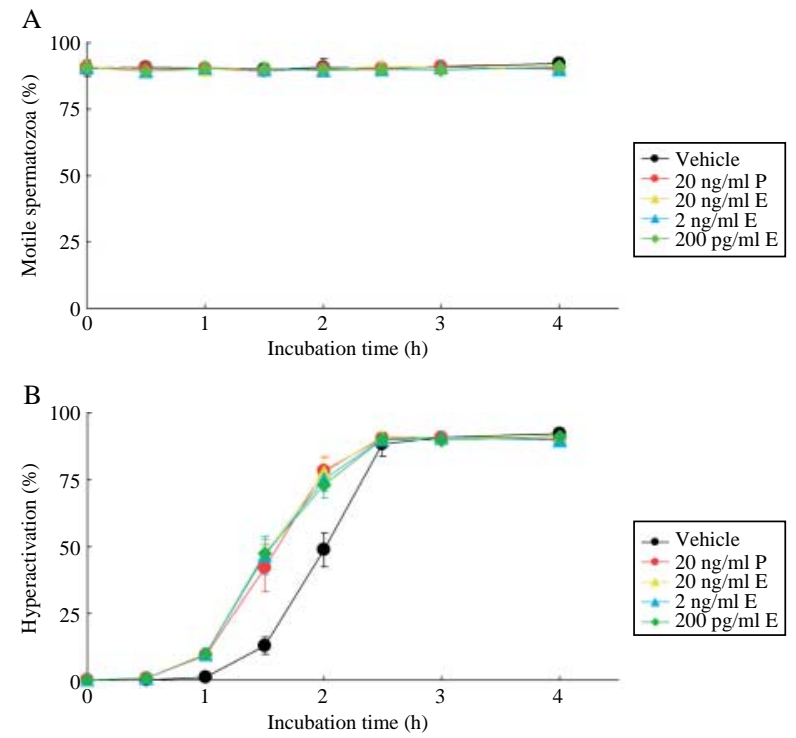

Figure 5 Effects of $17 \alpha \mathrm{E}_{2}$ on the percentage of motile spermatozoa and progesterone-enhanced hyperactivation. After exposure to $17 \alpha \mathrm{E}_{2}$ for $5 \mathrm{~min}$, spermatozoa were exposed to $20 \mathrm{ng} / \mathrm{ml}$ progesterone. The percentage of motile spermatozoa (A) and hyperactivation (B) are shown when $17 \alpha \mathrm{E}_{2}$ and progesterone were added to mTALP medium. Data are expressed as mean \pm s.D. (Vehicle), $\mathrm{mTALP}+0.2 \%(\mathrm{v} / \mathrm{v})$ $\mathrm{EtOH} ;(20 \mathrm{ng} / \mathrm{ml}$ progesterone), $\mathrm{mTALP}+20 \mathrm{ng} / \mathrm{ml}$ progesterone $+0.2 \%(\mathrm{v} / \mathrm{v}) \mathrm{EtOH} ;(20 \mathrm{ng} / \mathrm{ml} \mathrm{E}), \mathrm{mTALP}+20 \mathrm{ng} / \mathrm{ml} 17 \alpha \mathrm{E}_{2}+20 \mathrm{ng} / \mathrm{ml}$ progesterone $+0.2 \%(\mathrm{v} / \mathrm{v}) \mathrm{EtOH} ;(2 \mathrm{ng} / \mathrm{ml} \mathrm{E}), \mathrm{mTALP}+2 \mathrm{ng} / \mathrm{ml}$ $17 \alpha \mathrm{E}_{2}+20 \mathrm{ng} / \mathrm{ml}$ progesterone $+0.2 \%(\mathrm{v} / \mathrm{v}) \mathrm{EtOH} ;(200 \mathrm{pg} / \mathrm{ml} \mathrm{E})$, $\mathrm{mTALP}+200 \mathrm{pg} / \mathrm{ml} 17 \alpha \mathrm{E}_{2}+20 \mathrm{ng} / \mathrm{ml}$ progesterone $+0.2 \%(\mathrm{v} / \mathrm{v})$ $\mathrm{EtOH}$. All spermatozoa exposed to progesterone showed significant enhancement of hyperactivation compared with vehicle $(P<0.05)$. progesterone-enhanced hyperactivation was unaffected by $17 \alpha \mathrm{E}_{2}$. 

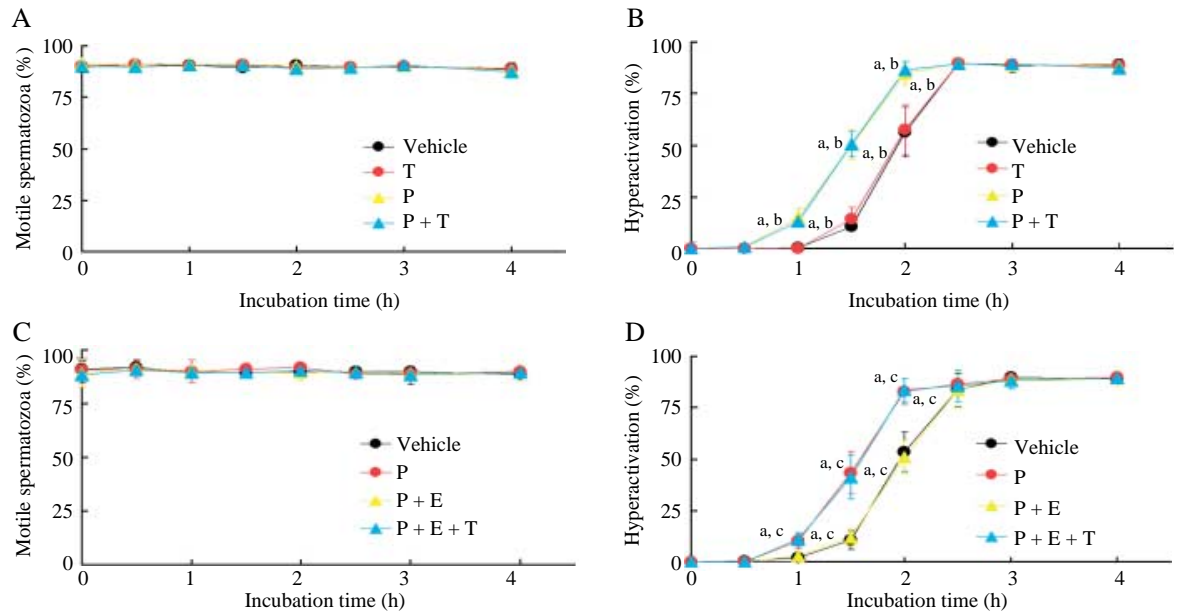

Figure 6 Inhibition of suppression of progesterone-enhanced hyperactivation by $17 \beta \mathrm{E}_{2}$. After exposure to $1 \mu \mathrm{mol} / \mathrm{I}$ tamoxifen for $5 \mathrm{~min}$, spermatozoa were exposed to $20 \mathrm{ng} / \mathrm{ml} 17 \beta \mathrm{E}_{2}$. After incubation for $5 \mathrm{~min}$, they were exposed to $20 \mathrm{ng} / \mathrm{ml}$ progesterone. The percentage of motile spermatozoa (A) and hyperactivation (B) are shown when tamoxifen and progesterone were added to the mTALP medium. The percentage of motile spermatozoa (C) and hyperactivation $(\mathrm{D})$ are shown when tamoxifen, $17 \beta \mathrm{E}_{2}$, and progesterone were added to mTALP medium. Data are expressed as mean \pm s.D. (Vehicle), mTALP + 0.1\% (v/v) ethanol $+0.1 \%(\mathrm{v} / \mathrm{v}) \mathrm{DMSO} ;(\mathrm{P}), \mathrm{mTALP}+20 \mathrm{ng} / \mathrm{ml}$ progesterone $+0.1 \%(\mathrm{v} / \mathrm{v}) \mathrm{EtOH}+0.1 \%(\mathrm{v} / \mathrm{v}) \mathrm{DMSO} ;(\mathrm{T})$, $\mathrm{mTALP}+1 \mu \mathrm{mol} / \mathrm{l}$ tamoxifen $+0.1 \%(\mathrm{v} / \mathrm{v}) \mathrm{EtOH}+0.1 \%(\mathrm{v} / \mathrm{v}) \mathrm{DMSO} ;(\mathrm{P}+\mathrm{T}), \mathrm{mTALP}+1 \mu \mathrm{mol} / \mathrm{l}$ tamoxifen $+20 \mathrm{ng} / \mathrm{ml}$ progesterone $+0.1 \%(\mathrm{v} / \mathrm{v})$ $\mathrm{EtOH}+0.1 \%(\mathrm{v} / \mathrm{v}) \mathrm{DMSO} ;(\mathrm{P}+\mathrm{E}), \mathrm{mTALP}+20 \mathrm{ng} / \mathrm{ml} 17 \beta \mathrm{E}_{2}+20 \mathrm{ng} / \mathrm{ml}$ progesterone $+0.1 \%(\mathrm{v} / \mathrm{v}) \mathrm{EtOH}+0.1 \%(\mathrm{v} / \mathrm{v}) \mathrm{DMSO} ;(\mathrm{P}+\mathrm{E}+\mathrm{T}), \mathrm{mTALP}$

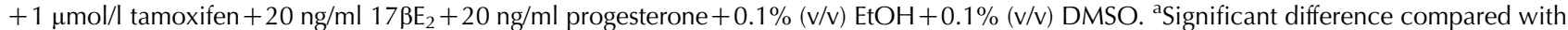
vehicle $(P<0.05)$; ${ }^{\mathrm{b}}$ Significant difference compared with $\mathrm{T}(P<0.05)$; ${ }^{\mathrm{c}}$ Significant difference compared with progesterone $+\mathrm{E}(P<0.05)$.

\section{Effects of $17 \beta E_{2}$ on tyrosine phosphorylations}

It is accepted that tyrosine phosphorylations are an important event in sperm hyperactivation (Yanagimachi 1994, Visconti et al. 1995, Visconti \& Kopf 1998, Fujinoki et al. 2006, Fujinoki 2009). A previous study (Noguchi et al. 2008) suggested that tyrosine phosphorylations in hamster spermatozoa were enhanced by $20 \mathrm{ng} / \mathrm{ml}$ progesterone.

As shown in Fig. 9B, several tyrosine phosphorylations occurred during hyperactivation in a time-dependent manner. Four tyrosine phosphorylations, designated as 80u, 85u, 80ut, and 85ut (Fujinoki et al. 2006), were enhanced by $20 \mathrm{ng} / \mathrm{ml}$ progesterone (Noguchi et al. 2008; Fig. 9D). Phosphorylations of $80 u$ and $85 u$ were detected in the urea extract (Fujinoki et al. 2006; Fig. 9B lanes a-f). Phosphorylations of 80ut and 85ut were detected in the urea-thiourea extract (Fujinoki et al. 2006; Fig. 9B lanes g-I).

When hamster spermatozoa were exposed to $20 \mathrm{ng} / \mathrm{ml} 17 \beta \mathrm{E}_{2}$, tyrosine phosphorylations including $80 u$ and $85 u$ were not detected in the urea extract (Fig. 9C lanes a-f), although $20 \mathrm{ng} / \mathrm{ml} 17 \beta \mathrm{E}_{2}$ itself did not affect the percentage of motile spermatozoa and hyperactivation (Fig. 1). On the other hand, tyrosine phosphorylations were detected in the urea-thiourea extract when spermatozoa were exposed to $20 \mathrm{ng} / \mathrm{ml}$ $17 \beta \mathrm{E}_{2}$ (Fig. 9C lanes g-l). When spermatozoa were exposed to $20 \mathrm{ng} / \mathrm{ml}$ progesterone, tyrosine phosphorylations of $80 u, 85 u, 80 u t$ and $85 u t$ were enhanced when compared with vehicle (Fig. 9B and D). As shown in
Fig. 9E lanes a-f, tyrosine phosphorylations were not detected in the urea extract when spermatozoa were exposed to $20 \mathrm{ng} / \mathrm{ml} 17 \beta \mathrm{E}_{2}$ before they were exposed to $20 \mathrm{ng} / \mathrm{ml}$ progesterone. The tyrosine phosphorylations detected in the urea-thiourea extract, as shown in Fig. 9E lanes $\mathrm{g}-\mathrm{l}$, were the same as the tyrosine phosphorylations as shown in Fig. 9C lanes g-l. Under the same conditions, progesterone-enhanced hyperactivation was suppressed (Fig. 2). As shown in Fig. 6, $1 \mu \mathrm{mol} / \mathrm{l}$ tamoxifen canceled the effect of $20 \mathrm{ng} / \mathrm{ml} 17 \beta \mathrm{E}_{2}$ on progesterone-enhanced hyperactivation. For tyrosine phosphorylations, $1 \mu \mathrm{mol} / \mathrm{l}$ tamoxifen inhibited the effect of $20 \mathrm{ng} / \mathrm{ml} 17 \beta \mathrm{E}_{2}$ (Fig. 9F).

\section{Discussion}

The AR is induced in a ligand-dependent manner. Progesterone is a major ligand of the AR (Osman et al. 1989, Baldi et al. 1998, 2009, Lösel \& Wehling 2003, Luconi et al. 2004). On the other hand, progesterone also enhances sperm hyperactivation (Sueldo et al. 1993, Noguchi et al. 2008). Recently, melatonin was also shown to be a ligand that enhances sperm hyperactivation in hamster (Fujinoki 2008). It would therefore appear that hyperactivation is enhanced by ligands (Fujinoki 2009).

Progesterone-induced AR is suppressed by $17 \beta \mathrm{E}_{2}$ through non-genomic regulation in human spermatozoa (Luconi et al. 1999, 2004, Baldi et al. 2000, 2009). In the present study, I showed that $17 \beta \mathrm{E}_{2}$ suppresses progesterone-enhanced hyperactivation through 

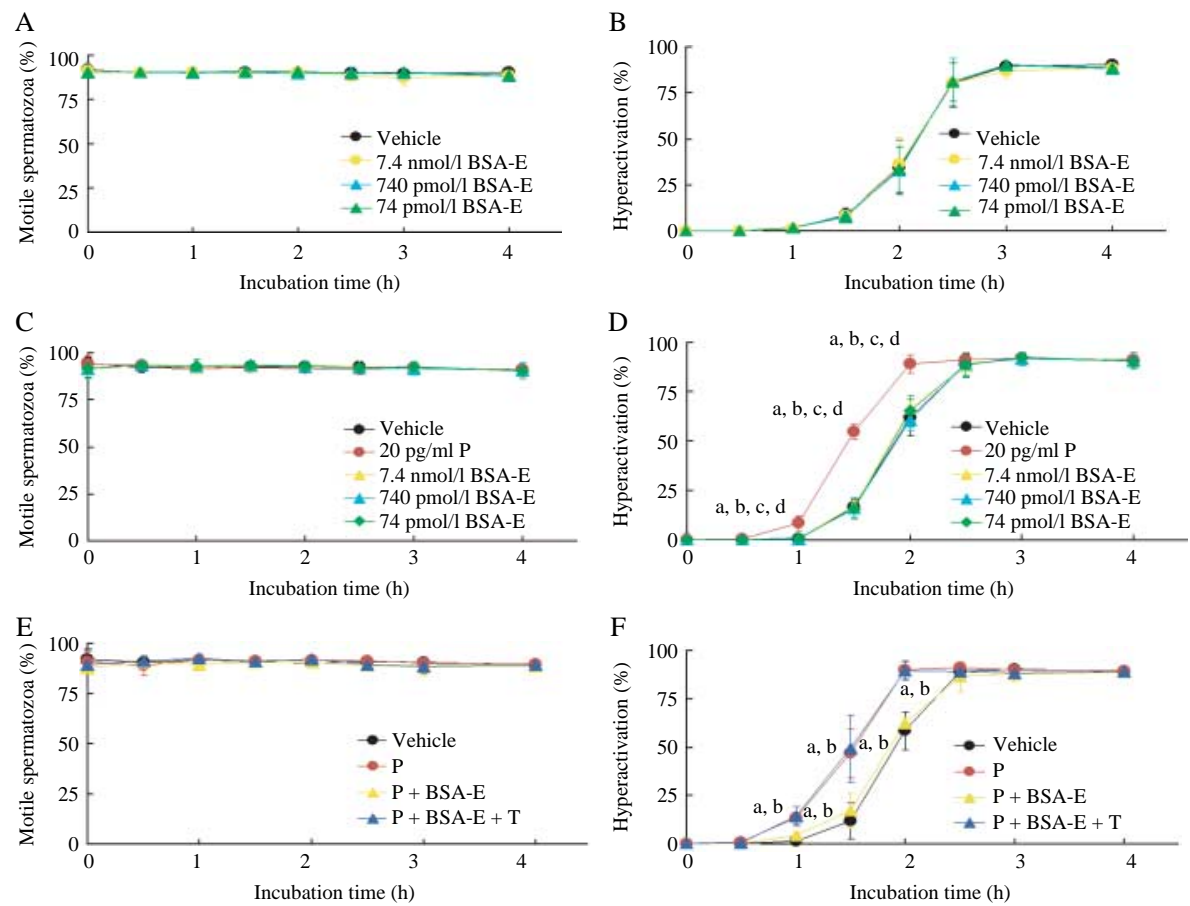

Figure 7 Suppression of progesterone-enhanced hyperactivation by $17 \beta \mathrm{E}_{2}$ via non-genomic regulation. After exposure to $1 \mu \mathrm{mol} / \mathrm{l}$ tamoxifen for

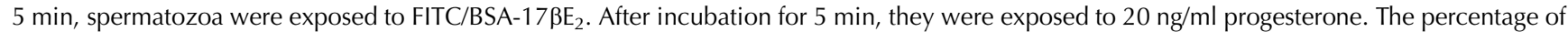
motile spermatozoa (A) and hyperactivation (B) are shown when only FITC/BSA-17 $\beta \mathrm{E}_{2}$ was added to mTALP medium. The percentage of motile spermatozoa $(C)$ and hyperactivation $(D)$ are shown when FITC/BSA-17 $\beta E_{2}$ and progesterone were added to mTALP medium. The percentage of motile spermatozoa $(\mathrm{E})$ and hyperactivation $(\mathrm{F})$ are shown when tamoxifen, $\mathrm{FITC} / \mathrm{BSA}-17 \beta \mathrm{E}_{2}$, and progesterone were added to mTALP medium. Data are expressed as mean \pm s.D. (Vehicle), $\mathrm{mTALP}+0.1 \%(\mathrm{v} / \mathrm{v})$ ethanol $+0.1 \%(\mathrm{v} / \mathrm{v}) \mathrm{DMSO} ;(20 \mathrm{ng} / \mathrm{ml}$ progesterone or progesterone), $\mathrm{mTALP}+20 \mathrm{ng} / \mathrm{ml}$ progesterone $+0.1 \%(\mathrm{v} / \mathrm{v}) \mathrm{EtOH}+0.1 \%(\mathrm{v} / \mathrm{v}) \mathrm{DMSO} ;(7.4 \mathrm{nmol} / \mathrm{l}$ BSA-E or progesterone+ BSA-E), mTALP $+7.4 \mathrm{nmol} / \mathrm{l} \mathrm{FITC} / \mathrm{BSA}-17 \mathrm{BE}_{2}+20 \mathrm{ng} / \mathrm{ml}$ progesterone $+0.1 \%(\mathrm{v} / \mathrm{v}) \mathrm{EtOH}+0.1 \%(\mathrm{v} / \mathrm{v}) \mathrm{DMSO} ;(740 \mathrm{pmol} / \mathrm{l} \mathrm{BSA}-\mathrm{E}), \mathrm{mTALP}+740 \mathrm{pmol} / \mathrm{l} \mathrm{FITC} / \mathrm{BSA}-$ $17 \beta \mathrm{E}_{2}+20 \mathrm{ng} / \mathrm{ml}$ progesterone $+0.1 \%(\mathrm{v} / \mathrm{v}) \mathrm{EtOH}+0.1 \%(\mathrm{v} / \mathrm{v}) \mathrm{DMSO} ;(74 \mathrm{pmol} / \mathrm{l} \mathrm{BSA-E}), \mathrm{mTALP}+74 \mathrm{pmol} / \mathrm{l} \mathrm{FITC} / \mathrm{BSA}^{2} 17 \beta \mathrm{E}_{2}+20 \mathrm{ng} / \mathrm{ml}$ progesterone $+0.1 \%(\mathrm{v} / \mathrm{v}) \mathrm{EtOH}+0.1 \%(\mathrm{v} / \mathrm{v}) \mathrm{DMSO} ;(\mathrm{P}+\mathrm{BSA}-\mathrm{E}+\mathrm{T}), \mathrm{mTALP}+1 \mu \mathrm{mol} / \mathrm{l}$ tamoxifen $+7.4 \mathrm{nmol} / \mathrm{l} \mathrm{FITC} / \mathrm{BSA}-17 \beta \mathrm{E}_{2}+20 \mathrm{ng} / \mathrm{ml}$ progesterone $+0.1 \%(\mathrm{v} / \mathrm{v}) \mathrm{EtOH}+0.1 \%(\mathrm{v} / \mathrm{v})$ DMSO. ${ }^{\mathrm{a} S i g n i f i c a n t ~ d i f f e r e n c e ~ c o m p a r e d ~ w i t h ~ v e h i c l e ~}(P<0.05)$; ${ }^{\mathrm{b}}$ Significant difference compared with $7.4 \mathrm{nmol} / \mathrm{I}$ FITC/BSA-E or progesterone+FITC/BSA-E $(P<0.05)$; ${ }^{\mathrm{C}}$ Significant difference compared with $740 \mathrm{pmol} / \mathrm{I} \mathrm{FITC/BSA-E}(P<0.05)$; ${ }^{\mathrm{d}}$ Significant difference compared with $74 \mathrm{pmol} / \mathrm{I}$ FITC/BSA-E $(P<0.05)$.

non-genomic regulation in hamster spermatozoa (see Figs $2,3,6$ and 7 ). Since $17 \beta \mathrm{E}_{2}$ binds to the acrosome region of the sperm head (see Fig. 8), it appears that signals of $17 \beta \mathrm{E}_{2}$ start at the sperm head and are transmitted to the sperm flagellum. Calcium is a key molecule in the regulation of AR and hyperactivation by steroid hormones (Luconi et al. 1999, 2004, Baldi et al. 2000, 2009, Noguchi et al. 2008, Fujinoki 2009). After progesterone binds to the sperm head, it stimulates calcium influx and activation of PLC (Fukami et al. 2003, Lösel \& Wehling 2003, Harper et al. 2004, Luconi et al. 2004, Noguchi et al. 2008, Baldi et al. 2009, Fujinoki 2009). Moreover, spermatozoa are not hyperactivated in the mTALP medium without calcium (Fujinoki 2008, Noguchi et al. 2008). In human spermatozoa, $17 \beta \mathrm{E}_{2}$ also stimulates calcium influx and suppresses progesteroneinduced AR (Luconi et al. 1999, 2004, Baldi et al. 2000, 2009). Although the $17 \beta \mathrm{E}_{2}$ signal is unknown, it is likely that the $17 \beta \mathrm{E}_{2}$ signal differs from progesterone signals and suppresses progesterone signals via calcium influx
(Luconi et al. 1999, 2004, Baldi et al. 2000, 2009). In the present study, I did not examine calcium influx induced by $17 \beta \mathrm{E}_{2}$ in hamster spermatozoa. Based on the assumption that $17 \beta \mathrm{E}_{2}$ stimulates calcium influx, in a future study, I will investigate the relationship between $17 \beta \mathrm{E}_{2}$ and calcium influx using hamster spermatozoa.

When spermatozoa are hyperactivated, a major intracellular signaling event that occurs is tyrosine phosphorylation (Yanagimachi 1994, Visconti \& Kopf 1998, Visconti et al. 1998, Ho \& Suarez 2001, Ho et al. 2002, Fujinoki et al. 2006, Fujinoki 2009). As part of progesterone-enhanced hyperactivation, progesterone enhances tyrosine phosphorylations of 80 and $85 \mathrm{kDa}$ proteins such as $80 \mathrm{u}, 85 \mathrm{u}, 80 \mathrm{ut}$, and $85 \mathrm{ut}$ (Noguchi et al. 2008; see Figs 2 and 9). Interestingly, $17 \beta \mathrm{E}_{2}$ partially suppressed tyrosine phosphorylations (see Fig. 9C), and $17 \beta \mathrm{E}_{2}$ suppressed progesterone-enhanced tyrosine phosphorylations (see Fig. 9E). Tamoxifen inhibited the suppression of progesterone-enhanced tyrosine phosphorylations by $17 \beta \mathrm{E}_{2}$ (see Fig. 9F), although it did not 

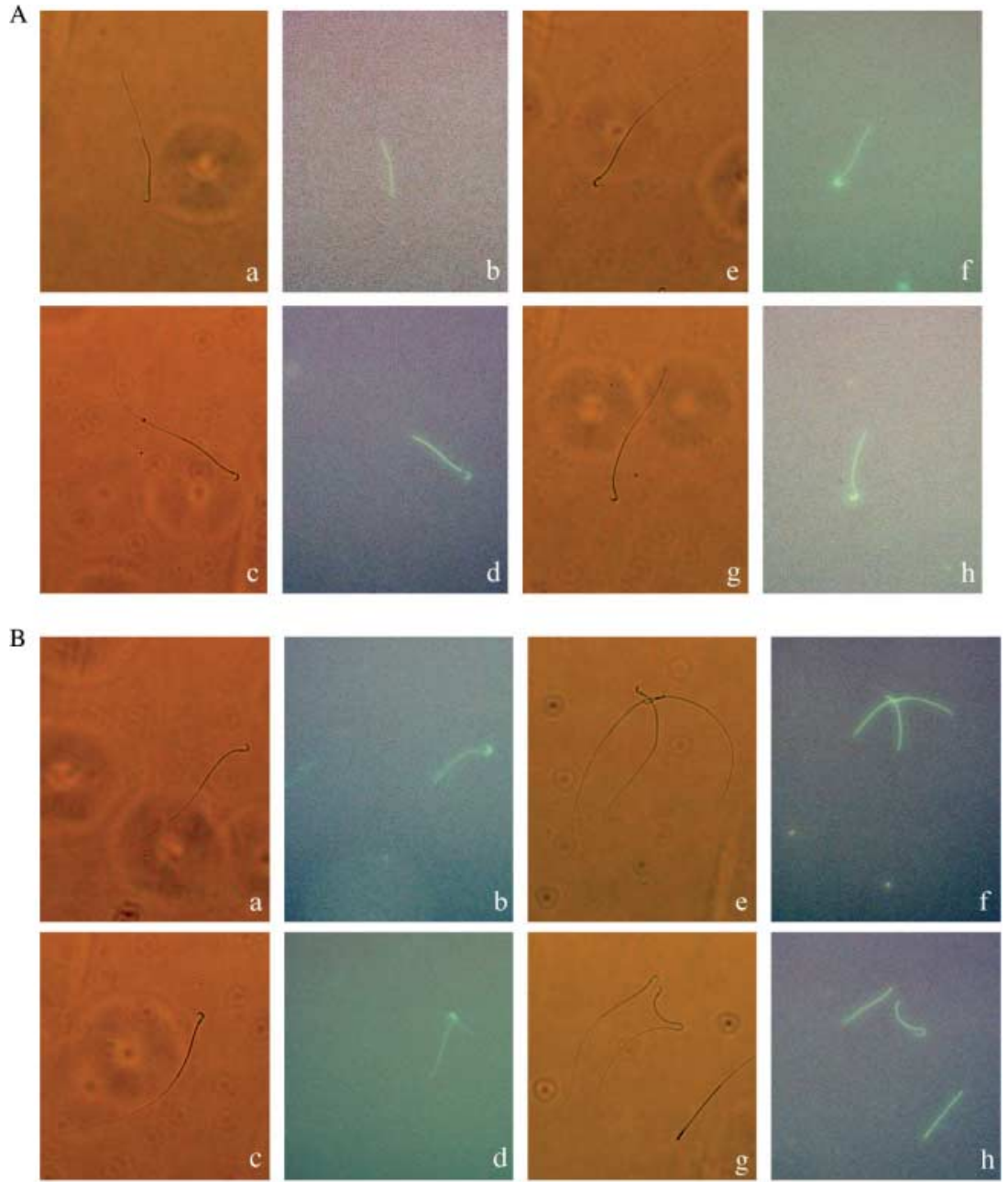

C
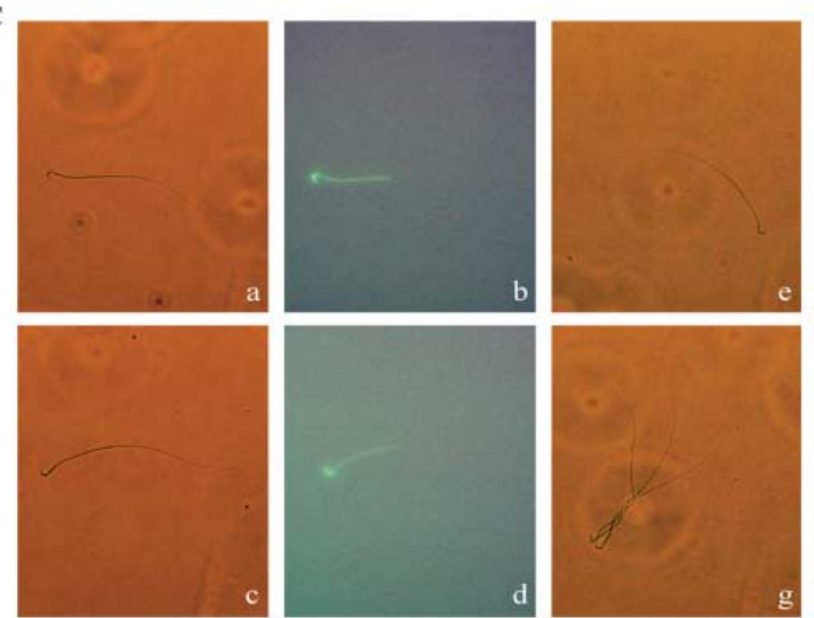
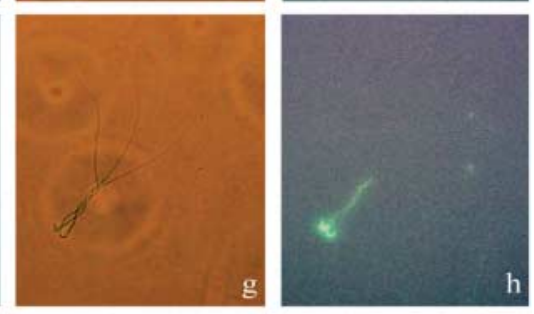

$100 \mu \mathrm{m}$
Figure 8 Binding of steroid hormones to spermatozoa. (A) Binding of $17 \beta \mathrm{E}_{2}$ and progesterone to sperm head. ( $a$ and b) Hamster spermatozoa were incubated in mTALP medium with $0.1 \%(\mathrm{v} / \mathrm{v})$ $\mathrm{EtOH}$ and $0.1 \%(\mathrm{v} / \mathrm{v})$ DMSO. (c and d) Hamster spermatozoa were incubated in mTALP with $7 \mathrm{nmol} / \mathrm{I} \mathrm{FITC/BSA-P,} 0.1 \%(\mathrm{v} / \mathrm{v}) \mathrm{EtOH}$, and $0.1 \%$ (v/v) DMSO. (e-h) Hamster spermatozoa were incubated in mTALP medium with $7.4 \mathrm{nmol} / \mathrm{I}$ FITC/BSA-17ßE $2,0.1 \%(\mathrm{v} / \mathrm{v}) \mathrm{EtOH}$, and $0.1 \%(\mathrm{v} / \mathrm{v})$ DMSO. (B) Effect of tamoxifen on binding of $17 \beta \mathrm{E}_{2}$ to the sperm head. (a-d) Hamster spermatozoa were incubated in mTALP medium with $7.4 \mathrm{nmol} / \mathrm{l}$ FITC/BSA-17ß $\mathrm{E}_{2}, 1 \mu \mathrm{mol} / \mathrm{l}$ tamoxifen, $0.1 \%(\mathrm{v} / \mathrm{v})$ $\mathrm{EtOH}$, and $0.1 \%(\mathrm{v} / \mathrm{v})$ DMSO. (e-h) Hamster spermatozoa were incubated in mTALP medium with $1 \mu \mathrm{mol} / \mathrm{l}$ tamoxifen, $0.1 \%(\mathrm{v} / \mathrm{v}) \mathrm{EtOH}$, and $0.1 \%(\mathrm{v} / \mathrm{v})$ DMSO. (C) Effect of steroid hormones on binding of steroid hormones to the sperm head. (a-d) Hamster spermatozoa were incubated in mTALP medium with $7 \mathrm{nmol} / \mathrm{I} \mathrm{FITC/BSA-P} \mathrm{after}$ exposure to $20 \mathrm{ng} / \mathrm{ml} 17 \beta \mathrm{E}_{2}, 0.1 \%(\mathrm{v} / \mathrm{v}) \mathrm{EtOH}$, and $0.1 \%(\mathrm{v} / \mathrm{v})$ DMSO. (e-h) Hamster spermatozoa were incubated in mTALP medium with $7.4 \mathrm{nmol} / \mathrm{l}$ FITC/BSA-17 $\beta \mathrm{E}_{2}$ after exposure to $20 \mathrm{ng} / \mathrm{ml}$ progesterone, $0.1 \%(\mathrm{v} / \mathrm{v}) \mathrm{EtOH}$, and $0.1 \%(\mathrm{v} / \mathrm{v})$ DMSO. (a, c, e, g in A-C) Observed under visible light; (b, d, f, h in A-C) observed under fluorescence. Fluorescence of the mitochondrial sheath in the flagellum appeared to be autofluorescence. Bar represents $100 \mu \mathrm{m}$. inhibit the binding of $17 \beta \mathrm{E}_{2}$ at the sperm head (see Fig. 8B). Tyrosine phosphorylation of proteins detected in the urea extract was suppressed by $17 \beta \mathrm{E}_{2}$ (see Fig. 9C). The urea extract contained proteins from many sperm structures, except the fibrous sheath and head
(Fujinoki et al. 2006). On the other hand, tyrosine phosphorylation of proteins detected in the urea-thiourea extract was unaffected (see Fig. 9C). The urea-thiourea extract contained proteins of fibrous sheath (Fujinoki et al. 2006). One of the tyrosine phosphorylations 


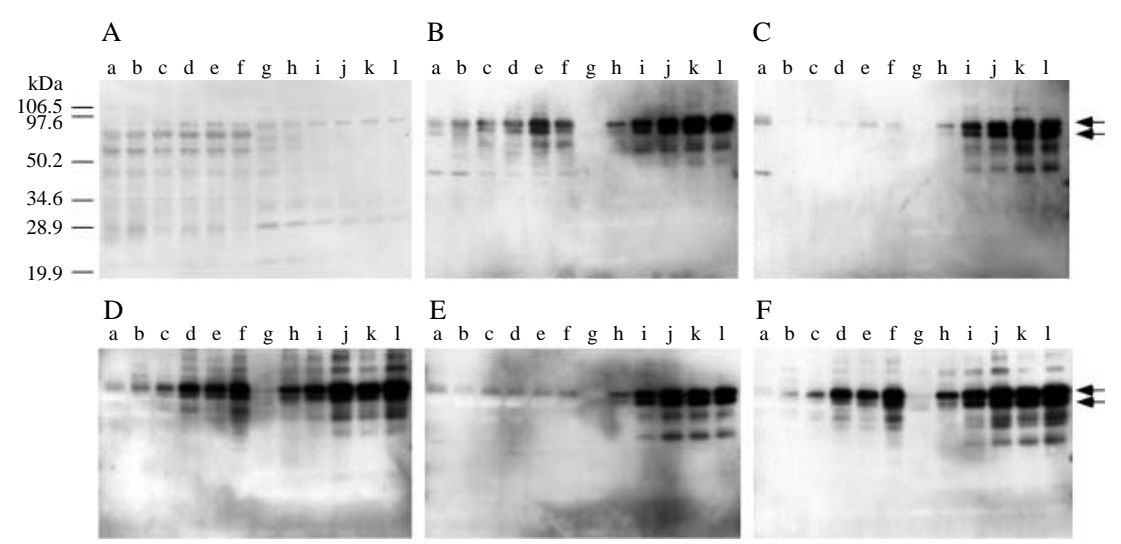

Figure 9 Changes in tyrosine phosphorylations associated with hyperactivation regulated by steroid hormones. Tyrosine phosphorylations were detected by western blotting using anti-phosphotyrosine MAB (clone, PT-66). (A) Typical CBB-stained membrane after blotting. (B) Western blotting against proteins obtained from spermatozoa that were incubated in mTALP medium with $0.2 \%(\mathrm{v} / \mathrm{v}) \mathrm{EtOH}$ and $0.1 \%(\mathrm{v} / \mathrm{v}) \mathrm{DMSO}$. (C) Western blotting against proteins obtained from spermatozoa that were incubated in mTALP medium with $20 \mathrm{ng} / \mathrm{ml} 17 \beta \mathrm{E}_{2}, 0.2 \%(\mathrm{v} / \mathrm{v}) \mathrm{EtOH}$, and $0.1 \%(\mathrm{v} / \mathrm{v})$ DMSO. (D) Western blotting against proteins obtained from spermatozoa that were incubated in mTALP medium with $20 \mathrm{ng} / \mathrm{ml} \mathrm{progesterone,} 0.2 \%$ $(\mathrm{v} / \mathrm{v}) \mathrm{EtOH}$, and $0.1 \%(\mathrm{v} / \mathrm{v})$ DMSO. (E) Western blotting against proteins obtained from spermatozoa that were incubated in mTALP medium with $20 \mathrm{ng} / \mathrm{ml} 17 \beta \mathrm{E}_{2}, 20 \mathrm{ng} / \mathrm{ml}$ progesterone, $0.2 \%(\mathrm{v} / \mathrm{v}) \mathrm{EtOH}$, and $0.1 \%(\mathrm{v} / \mathrm{v}) \mathrm{DMSO}$. Hamster spermatozoa were exposed to $20 \mathrm{ng} / \mathrm{ml} \mathrm{progesterone}$ after exposure to $20 \mathrm{ng} / \mathrm{ml} 17 \beta \mathrm{E}_{2}$ for $5 \mathrm{~min}$. (F) Western blotting against proteins obtained from spermatozoa that were incubated in mTALP medium with $20 \mathrm{ng} / \mathrm{ml} 17 \beta \mathrm{E}_{2}, 20 \mathrm{ng} / \mathrm{ml}$ progesterone, $1 \mu \mathrm{mol} / \mathrm{l}$ tamoxifen, $0.2 \%(\mathrm{v} / \mathrm{v}) \mathrm{EtOH}$, and $0.1 \%(\mathrm{v} / \mathrm{v}) \mathrm{DMSO}$. Hamster spermatozoa were exposed to $20 \mathrm{ng} / \mathrm{ml} 17 \beta \mathrm{E}_{2}$ after exposure to $1 \mu \mathrm{mol} / \mathrm{l}$ tamoxifen for $5 \mathrm{~min}$. After incubation for $5 \mathrm{~min}$, they were exposed to $20 \mathrm{ng} / \mathrm{ml}$ progesterone. Lanes a-f and $\mathrm{g}-\mathrm{l}$ illustrate results obtained from the urea extract and the urea-thiourea extract respectively. Lanes a and $\mathrm{g}$ were incubated for $0 \mathrm{~h}$, lanes $\mathrm{b}$ and $\mathrm{h}$ were incubated for $0.5 \mathrm{~h}$, lanes $\mathrm{c}$ and i were incubated for $1 \mathrm{~h}$, lanes $\mathrm{d}$ and $\mathrm{j}$ were incubated for $2 \mathrm{~h}$, lanes e and k were incubated for $3 \mathrm{~h}$, and lanes $\mathrm{f}$ and I were incubated for $4 \mathrm{~h}$. SDS-PAGE was performed on $5 \mu \mathrm{l}$ samples per lane. Arrows show tyrosine phosphorylation of 80 and $85 \mathrm{kDa}$ proteins. Numbers on the left side of (A) indicate the molecular weight standard.

associated with hyperactivation is that of AKAP, 80 and/ or $85 \mathrm{kDa}$ components of the fibrous sheath (Carrera et al. 1996, Jha \& Shivaji 2002). Therefore, tyrosine phosphorylations of 80 and/or $85 \mathrm{kDa}$ proteins detected in the urea-thiourea extract (80ut and 85ut) corresponded to AKAP and were not affected by $17 \beta \mathrm{E}_{2}$, although they were affected by progesterone (Noguchi et al. 2008; see Fig. 9C and D). Because hamster spermatozoa were hyperactivated in the presence of $17 \beta \mathrm{E}_{2}$, it is likely that tyrosine phosphorylations of 80ut and 85ut are associated with the essential regulatory mechanisms of hyperactivation. Because tyrosine phosphorylation of AKAP is regulated by calcium signals associated with calcium/calmodulin-dependent protein kinase (Carrera et al. 1996), it seems that tyrosine phosphorylations of $80 \mathrm{ut}$ and $85 \mathrm{ut}$ are regulated by calcium signals associated with calcium/calmodulindependent kinase. At least, tyrosine phosphorylations of 80ut and 85ut were enhanced by progesterone through calcium signals associated with PLC (Noguchi et al. 2008). On the other hand, tyrosine phosphorylations of 80 and $85 \mathrm{kDa}$ proteins detected in the urea extract $(80 \mathrm{u}$ and $85 \mathrm{u}$ ) were suppressed by $17 \beta \mathrm{E}_{2}$ and enhanced by progesterone (Noguchi et al. 2008; see Fig. 9C and D). Even if $80 u, 85 u$, and other proteins detected in the urea extract were not phosphorylated at tyrosine residues by $17 \beta \mathrm{E}_{2}$, spermatozoa were hyperactivated (see Figs 2 and 9C). These results suggest that tyrosine phosphorylations detected in the urea extract are not associated with the essential regulatory mechanisms of hyperactivation. Because tyrosine phosphorylations detected in the urea extract responded to the effects of steroid hormones, however, it is likely that they are associated with modulatory mechanisms of hyperactivation. Although tyrosine phosphorylations of $80 \mathrm{u}$ and $85 \mathrm{u}$ are enhanced by progesterone (Noguchi et al. 2008; see Fig. 9D), their regulatory mechanisms are not known at all and have not been identified yet. In a future study, I will investigate the regulatory mechanism of tyrosine phosphorylation of $80 \mathrm{u}$ and $85 \mathrm{u}$ and their identification.

In the present study, I demonstrated that enhancement of sperm hyperactivation was competitively regulated by steroid hormones (see Figs 2 and 3). It is suggested that the $A R$ is also competitively regulated by steroid hormones (Luconi et al. 1999, 2004, Baldi et al. 2000, 2009). For both the AR and the hyperactivation, progesterone enhances the functions and $17 \beta \mathrm{E}_{2}$ suppresses the effects of progesterone (Luconi et al. 1999, 2004, Baldi et al. 2000, 2009, Noguchi et al. 2008, Fujinoki 2009; see Figs 2 and 3). The hyperactivation threshold concentration of $17 \beta \mathrm{E}_{2}$ was $20 \mathrm{pg} / \mathrm{ml}$ when spermatozoa were exposed to $17 \beta \mathrm{E}_{2}$ before exposure to $20 \mathrm{ng} / \mathrm{ml}$ progesterone (see Fig. 2). When spermatozoa were exposed to both steroid hormones at the same time, the threshold concentration of $17 \beta \mathrm{E}_{2}$ was $200 \mathrm{pg} / \mathrm{ml}$ (see Fig. 3). Female mammals have an estrous or menstrual 
cycle, causing concentrations of $17 \beta \mathrm{E}_{2}$ and progesterone in the blood and tissues to fluctuate. The balance between the concentrations of $17 \beta \mathrm{E}_{2}$ and progesterone accordingly appears to regulate sperm $A R$ and hyperactivation. When $17 \mathrm{BE}_{2}$ is more dominant over progesterone, enhancement of $A R$ and hyperactivation is suppressed. Conversely, AR and hyperactivation are enhanced when progesterone is dominant over $17 \beta \mathrm{E}_{2}$. In a future study, I will examine the changes in sperm function under different patterns of $17 \beta \mathrm{E}_{2}$ and progesterone concentrations.

\section{Materials and Methods}

\section{Chemicals}

Anti-phosphotyrosine MAB (clone, PT-66), $17 \alpha \mathrm{E}_{2}, 17 \beta \mathrm{E}_{2}$, progesterone, FITC-conjugated and $\mathrm{BSA}$-conjugated $17 \beta \mathrm{E}_{2}$ (FITC/BSA-17 $\beta \mathrm{E}_{2}$ ), FITC-conjugated and BSA-conjugated progesterone (FITC/BSA-P), and tamoxifen were purchased from Sigma Chemical Company. BSA fraction $\mathrm{V}$ and Nonidet P-40 (NP-40) were purchased from Merck KGaA. ECL Plus kits and films for ECL were purchased from Amersham Biosciences. Other reagent grade chemicals were purchased from Wako Pure Chemical Industries (Osaka, Japan).

\section{Animals and preparation of hyperactivated spermatozoa}

Spermatozoa were obtained from the caudal epididymis of sexually mature (12-20 weeks old) male golden hamsters (Mesocricetus auratus). Hamsters were housed in accordance with the guidelines of the Dokkyo Medical University and the Laboratory Animal Research Center in Dokkyo Medical University of the care and use of laboratory animals.

Hyperactivated spermatozoa were prepared according to the method described previously (Fujinoki et al. 2006), using modified TALP (mTALP) medium containing $101.02 \mathrm{mmol} / \mathrm{l}$ $\mathrm{NaCl}, 2.68 \mathrm{mmol} / \mathrm{K} \mathrm{KCl}, 2 \mathrm{mmol} / \mathrm{CaCl}_{2}, 1.5 \mathrm{mmol} / \mathrm{l} \mathrm{MgCl} \mathrm{Mg}_{2}$. $6 \mathrm{H}_{2} \mathrm{O}, 0.36 \mathrm{mmol} / \mathrm{l} \mathrm{NaH}{ }_{2} \mathrm{PO}_{4} \cdot 2 \mathrm{H}_{2} \mathrm{O}, 35.70 \mathrm{mmol} / \mathrm{l} \mathrm{NaHCO}_{3}$, $4.5 \mathrm{mmol} / \mathrm{I} \mathrm{D}$-glucose, $0.09 \mathrm{mmol} / \mathrm{l}$ sodium pyruvate, $9 \mathrm{mmol} / \mathrm{I}$ sodium lactate, $0.5 \mathrm{mmol} / \mathrm{l}$ hypotaurine, $0.05 \mathrm{mmol} / \mathrm{l}$ (-)epinephrine, $0.2 \mathrm{mmol} / \mathrm{l}$ sodium taurochoric acid, $5.26 \mu \mathrm{mol} / \mathrm{l}$ sodium metabisulfite, $0.05 \%(\mathrm{w} / \mathrm{v})$ streptomycin sulfate, $0.05 \%(\mathrm{w} / \mathrm{v})$ potassium penicillin $\mathrm{G}$, and $15 \mathrm{mg} / \mathrm{ml}$ BSA (pH 7.4 at $37^{\circ} \mathrm{C}$ under $5 \%(v / v) C_{2}$ in air). An aliquot of caudal epididymal spermatozoa was placed in the bottom of a test tube, and several milliliters of the mTALP medium were carefully added, followed by incubation for $5 \mathrm{~min}$ to allow spermatozoa to swim up. The supernatant containing motile spermatozoa was collected, placed on a culture plate $(35 \mathrm{~mm}$ dish), and incubated for $4 \mathrm{~h}$ at $37^{\circ} \mathrm{C}$ under $5 \%(\mathrm{v} / \mathrm{v}) \mathrm{CO}_{2}$ in air to achieve hyperactivation. Steroid hormones and tamoxifen were dissolved in ethanol $(\mathrm{EtOH})$ and dimethyl sulfoxide (DMSO) respectively, and then added to the mTALP medium after placing the motile spermatozoa on the culture plate.

\section{Measurement of the percentage of motile spermatozoa and hyperactivation}

The percentage of motile spermatozoa and hyperactivation measurements were performed according to the method described in previous studies (Fujinoki et al. 2001b, 2006). Hamster spermatozoa suspended in the mTALP medium were diluted 10 -fold and placed on the culture plate (35 $\mathrm{mm}$ dish). Motile and hyperactivated spermatozoa were recorded on a DVD using a CCD camera (Progressive 3CCD, Sony Corp., Tokyo, Japan) attached to a microscope (IX70, Olympus Corp., Tokyo, Japan) with phase-contrast illumination and a small $\mathrm{CO}_{2}$ incubator (MI-IBC, Olympus). Each observation was performed at $37^{\circ} \mathrm{C}$ and recorded for $2 \mathrm{~min}$, and the analyses comprised counting the numbers of total spermatozoa, motile spermatozoa, and hyperactivated spermatozoa in 20 different fields. The percentage of motile spermatozoa and hyperactivation were respectively defined as (the number of motile spermatozoa/the number of total spermatozoa) $\times 100$ and (the number of hyperactivated spermatozoa/numbers of total spermatozoa) $\times 100$. Statistical analyses were performed using the post hoc test of ANOVA.

\section{Ligand assays of $17 \beta E_{2}$ and progesterone}

Ligand assays of $17 \beta \mathrm{E}_{2}$ and progesterone were performed according to the method described previously (Noguchi et al. 2008). An aliquot of caudal epididymal spermatozoa was placed on the bottom of a test tube, and several milliliters of mTALP medium with FITC/BSA- $17 \beta \mathrm{E}_{2}$ or FITC/BSA-P were carefully added, followed by incubation for 5 min to allow spermatozoa to swim up. The supernatant containing motile spermatozoa was collected, placed on a culture dish, and incubated for $5 \mathrm{~min}$ at $37{ }^{\circ} \mathrm{C}$ under $5 \%(\mathrm{v} / \mathrm{v}) \mathrm{CO}_{2}$ in air. After incubation, several microliters of the supernatant were placed on a glass slide without fluorescence and observed using a light microscope (IX70, Olympus) with phase-contrast illumination and a fluorescence unit.

\section{Preparation of sperm protein extracts}

Sperm proteins were extracted according to the method described previously (Fujinoki et al. 2006). In brief, spermatozoa were suspended at $30 \mathrm{mg}$ spermatozoa $/ \mathrm{ml}$ in the urea solution containing $7 \mathrm{~mol} / \mathrm{l}$ urea and $10 \%(\mathrm{v} / \mathrm{v})$ 2-mercaptoethanol. After pipetting, the suspension was incubated on ice for $10 \mathrm{~min}$. Following centrifugation at $15000 \mathrm{~g}$ for $10 \mathrm{~min}$ at $4{ }^{\circ} \mathrm{C}$, the supernatant was used as the urea extract. The precipitate was resuspended in the same volume of urea-thiourea solution containing $5 \mathrm{~mol} / \mathrm{l}$ urea, $1 \mathrm{~mol} / \mathrm{l}$ thiourea, $10 \%(\mathrm{v} / \mathrm{v})$ 2-mercaptoethanol, and $2 \%(\mathrm{v} / \mathrm{v}) \mathrm{NP}-40$ as the urea solution. After pipetting, the suspension was incubated on ice for $10 \mathrm{~min}$, centrifuged at $15000 \mathrm{~g}$ for $10 \mathrm{~min}$ at $4{ }^{\circ} \mathrm{C}$, and the supernatant was used as the urea-thiourea extract.

\section{SDS-PAGE}

SDS-PAGE was performed using the Laemmli protocol (Laemmli 1970) using a separating gel of $10 \%(\mathrm{w} / \mathrm{v})$ polyacrylamide containing $0.1 \%(\mathrm{w} / \mathrm{v})$ SDS. 


\section{Western blotting}

Western blotting was performed according to the method described previously (Fujinoki et al. 2001b, 2006). The blotted membrane was blocked with $5 \%(\mathrm{w} / \mathrm{v})$ skim milk in Trisbuffered saline (TBS) containing $0.15 \mathrm{~mol} / \mathrm{l} \mathrm{NaCl}$ and $20 \mathrm{mmol} / \mathrm{l}$ Tris- $\mathrm{HCl}\left(\mathrm{pH} \mathrm{7.5)}\right.$ for $1 \mathrm{~h}$ at $20^{\circ} \mathrm{C}$, and incubated with antiphosphotyrosine MAB (clone, PT-66) (1:1000 dilution with 5\% $(\mathrm{w} / \mathrm{v})$ skim milk in TBS) for $1 \mathrm{~h}$ at $20^{\circ} \mathrm{C}$. Following a TBS wash, the membrane was incubated with anti-mouse IgG antibodyconjugated peroxidase (1:5000 dilution with 5\% (w/v) skim milk in TBS). Color reactions were conducted using the ECL Plus kit.

\section{Declaration of interest}

The author declares that there is no conflict of interest that could be perceived as prejudicing the impartiality of the research reported.

\section{Funding}

This work was partially supported by a Grant-in-Aid for Young Scientists (B) from the Ministry of Education, Culture, Sports, Science and Technology of Japan (No. 15790860 and 18791135).

\section{References}

Baldi E, Luconi M, Bonaccorsi L \& Forti G 1998 Nongenomic effects of progesterone on spermatozoa: mechanisms of signal transduction and clinical implications. Frontiers in Bioscience 3 1051-1059.

Baldi E, Luconi M, Muratori M \& Forti G 2000 A novel functional estrogen receptor on human sperm membrane interferes with progesterone effects. Molecular and Cellular Endocrinology 161 31-35.

Baldi E, Luconi M, Muratori M, Marchiani S, Tamburrino L \& Forti G 2009 Nongenomic activation of spermatozoa by steroid hormones: facts and fictions. Molecular and Cellular Endocrinology 308 39-46.

Carrera A, Moos J, Ning XP, Gerton GL, Tesarik J, Kopf GS \& Moss SB 1996 Regulation of protein tyrosine phosphorylation in human sperm by a calcium/calmodulin-dependent mechanism: identification of A kinase anchoring proteins as major substrates for tyrosine phosphorylation. Developmental Biology 180 284-296.

Fujinoki M 2008 Melatonin-enhanced hyperactivation of hamster sperm. Reproduction 136 533-541.

Fujinoki M 2009 Non-genomic regulation of mammalian sperm hyperactivation. Reproductive Medicine and Biology 8 47-52.

Fujinoki M, Ohtake H \& Okuno M 2001a Serine phosphorylation of flagellar proteins associated with the motility activation of hamster spermatozoa. Biomedical Research 22 45-58.

Fujinoki M, Ohtake H \& Okuno M $2001 b$ Tyrosine phosphorylation and dephosphorylation associated with motility of hamster spermatozoa. Biomedical Research 22 147-155.

Fujinoki M, Suzuki T, Takayama T, Shibahara H \& Ohtake H 2006 Profiling of proteins phosphorylated or dephosphorylated during hyperactivation on hamster spermatozoa. Reproductive Medicine and Biology 5 123-135.

Fukami K, Yoshida M, Inoue T, Kurokawa M, Fissore RA, Yoshida N, Mikoshiba K \& Takenawa T 2003 Phospholipase $\mathrm{C} \delta 4$ is required for $\mathrm{Ca}^{2+}$ mobilization essential for acrosome reaction in sperm. Journal of Cell Biology 161 79-88.

Gadkar S, Shah CA, Sachdeva G, Samant U \& Puri CP 2002 Progesterone receptor as an indicator of sperm function. Biology of Reproduction 67 1327-1336.
Harper CV, Barratt CLR \& Publicover SJ 2004 Stimulation of human spermatozoa with progesterone gradients to stimulate approach to the oocyte. Journal of Biological Chemistry 279 46315-46325.

Harrison DA, Carr DW \& Meizel S 2000 Involvement of protein kinase $\mathrm{A}$ and $\mathrm{A}$ kinase anchoring protein in the progesterone-initiated human sperm acrosome reaction. Biology of Reproduction 62 811-820.

Ho HC \& Suarez SS 2001 An inositol 1,4,5-trisphoshate receptor-gated intracellular $\mathrm{Ca}^{2+}$ store is involved in regulating sperm hyperactivated motility. Biology of Reproduction 65 1606-1616.

Ho HC, Granish KA \& Suarez SS 2002 Hyperactivated motility of bull sperm is triggered at the axoneme by $\mathrm{Ca}^{2+}$ and not cAMP. Developmental Biology 250 208-217.

Jang S \& Yi LSH 2005 Identification of a $71 \mathrm{kDa}$ protein as a putative non-genomic membrane progesterone receptor in boar spermatozoa. Journal of Endocrinology 184 417-425.

Jha K \& Shivaji S 2001 Capacitation-associated changes in protein tyrosine phosphorylation, hyperactivation and acrosome reaction in hamster spermatozoa. Andrologia 33 95-104.

Jha K \& Shivaji S 2002 Identification of the major tyrosine phosphorylated protein of capacitated hamster spermatozoa as a homologue of mammalian sperm A kinase anchoring protein. Molecular Reproduction and Development 61 258-270.

Laemmli UK 1970 Cleavage of structural proteins during assembly of the head of bacteriophage T4. Nature 227 680-685.

Langlais J \& Roberts KD 1985 A molecular membrane model of sperm capacitation and the acrosome reaction of mammalian spermatozoa. Gamete Research 13 183-224.

Libersky EA \& Boatman DE 1995a Progesterone concentration in serum, follicular fluid, and oviductal fluid of the golden hamster during the periovulatory period. Biology of Reproduction 53 477-482.

Libersky EA \& Boatman DE 1995b Effects of progesterone on in vitro sperm capacitation and egg penetration in the golden hamster. Biology of Reproduction 53 483-487.

Llanos MN \& Anabalon MC 1996 Studies related to progesterone-induced hamster sperm acrosome reaction. Molecular Reproduction and Development 45 313-319.

Lösel R \& Wehling M 2003 Nongenomic actions of steroid hormones. Nature Reviews. Molecular Cell Biology 4 46-56.

Luconi M, Muratori M, Forti G \& Baldi E 1999 Identification and characterization of a novel functional estrogen receptor on human sperm membrane that interferes with progesterone effects. Journal of Clinical Endocrinology and Metabolism 84 1670-1678.

Luconi M, Francavilla F, Porazzi I, Macerola B, Forti G \& Baldi E 2004 Human spermatozoa as a model for studying membrane receptors mediating rapid nongenomic effects of progesterone and estrogens. Steroids 69 553-559.

Noguchi T, Fujinoki M, Kitazawa M \& Inaba N 2008 Regulation of hyperactivation of hamster spermatozoa by progesterone. Reproductive Medicine and Biology 7 63-74.

Okamura N, Tajima Y, Soejima A, Masuda H \& Sugita Y 1985 Sodium bicarbonate in seminal plasma stimulates the motility of mammalian spermatozoa through the direct activation of adenylate cyclase. Journal of Biological Chemistry 260 9699-9705.

Osman RA, Andria ML, Jones AD \& Meizel S 1989 Steroid induced exocytosis: the human sperm acrosome reaction. Biochemical and Biophysical Research Communications 160 828-833.

Sabeur K, Edwards DP \& Meizel S 1996 Human sperm plasma membrane progesterone receptor(s) and the acrosome reaction. Biology of Reproduction 54 993-1001.

Suarez SS \& Ho HC 2003 Hyperactivated motility in sperm. Reproduction in Domestic Animals 38 119-124.

Sueldo CE, Alexander NJ, Oehninger S, Burkman LJ, Subias E, Acosta AA \& Mahony M 1993 Effect of progesterone on human zona pellucida sperm binding and oocyte penetrationg capacity. Fertility and Sterility $\mathbf{6 0}$ 137-140.

Suzuki T, Fujinoki M, Shibahara H \& Suzuki M 2010 Regulation of hyperactivation by PP2A in hamster spermatozoa. Reproduction 139 847-856.

Visconti PE \& Kopf GS 1998 Regulation of protein phosphorylation during sperm capacitation. Biology of Reproduction 59 1-6. 
Visconti PE, Bailey JL, Moore GD, Pan D, Old-Clarke P \& Kopf GS 1995 Capacitation of mouse spermatozoa I. Correlation between the capacitation state and protein tyrosine phosphorylation. Development 121 1129-1137.

Visconti PE, Galantino-Homer H, Ning X, Fornes MW, Moore GD, Bailey JL \& Kopf GS 1998 The molecular basis of capacitation. Journal of Andrology 19 242-248.

Yanagimachi R 1994 Mammalian fertilization. In The Physiology of Reproduction, vol 2, edn 2, pp 189-317. Eds E Knobil \& JD Neill. New York: Raven Press.

Yang J, Serres C, Philibert D, Robel P, Baulieu EE \& Jouannet P 1994 Progesterone and RU486: opposing effects on human sperm. PNAS 91 529-533.
Yudin Al, Gottlieb W \& Meizel S 1988 Ultrastructural studies of the early events of the human sperm acrosome reaction as initiated by human follicular fluid. Gamete Research 20 11-24.

Received 7 April 2010

First decision 17 May 2010

Revised manuscript received 3 June 2010

Accepted 18 June 2010 